\title{
PENGARUH KEMAMPUAN KERJA DAN MOTIVASI KERJA TERHADAP KINERJA PEGAWAI KELURAHAN DI KECAMATAN MAULAFA DENGAN LINGKUNGAN KERJA DAN EFIKASI DIRI SEBAGAI VARIABEL MODERATOR
}

\author{
YOHANIS KAIMAREHE ${ }^{1}$, RAHMAT LAAN ${ }^{2}$, MUHRAN $^{3}$ \\ ${ }^{1}$ Mahasiswa Prodi Manajemen, Fakultas Ekonomi, Universitas Muhammadiyah Kupang \\ ${ }^{2}$ Dosen Prodi Manajemen, Fakultas Ekonomi, Universitas Muhammadiyah Kupang \\ ${ }^{3}$ Dosen Prodi Manajemen, Fakultas Ekonomi, Universitas Muhammadiyah Kupang
}

\begin{abstract}
ABSTRAK
Tujuan penelitian ini adalah untuk mengetahui pengaruh kemampuan kerja, motivasi kerja, lingkungan kerja dan efikasi diri terhadap kinerja pegawai maupun pengaruh kemampuan dan motivasi terhadap kinerja yang dimoderasi lingkungan kerja dan efikasi diri. Penelitian ini termasuk dalam kategori eksplanatory research. sampel sama dengan populasi yaitu sebanyak 118 pegawai atau menggunakan metode sensus, namun kuesioner yang terisi lengkap dan layak dianalisis sebanyak 66 responden. Data dianalisis menggunakan Smart-PLS 3.0. Hasil studi membuktikan bahwa secara statistik: kemampuan kerja berpengaruh tidak signifikan terhadap kinerja pegawai; motivasi kerja berpengaruh tidak signifikan terhadap kinerja pegawai; lingkungan kerja berpengaruh signifikan terhadap kinerja pegawai; efikasi diri berpengaruh signifikan terhadap kinerja pegawai;kemampuan kerja berpengaruh tidak signifikan terhadap kinerja pegawai yang dimoderasi lingkungan kerja; motivasi kerja berpengaruh signifikan terhadap kinerja pegawai yang dimoderasi lingkungan kerja; kemampuan kerja berpengaruh tidak signifikan terhadap kinerja pegawai yang dimoderasi efikasi diri; motivasi kerja berpengaruh tidak signifikan terhadap kinerja pegawai yang dimoderasi efikasi diri.
\end{abstract}

\section{Kata Kunci: Kemampuan Kerja, Motivasi Kerja, Lingkungan Kerja, Efikasi Diri, Kinerja Pegawai}

\section{PENDAHULUAN}

Kinerja pegawai birokrasi (Pegawai Negeri Sipil) di Indonesia masih cukup rendah sehingga dilakukan reformasi birokrasi, (Sedarmayanti, 2007:330; Kompas.com: 18 Agustus 2011; Pos Kupang.com: 10 Maret 2013; Merdeka.com: 19 Mei 2013). Tujuan reformasi birokrasi adalah mempertahankan dan meningkatkan kinerja pelayanan publik. Menurut Laan (2016:4) perbaikan dan peningkatan kualitas (kinerja) pelayanan publik merupakan salah satu sasaran sentral reformasi birokrasi yang digulirkan bangsa Indonesia di awal abad 21. Tujuan ini akan tercapai manakala tugas-tugas pelayanan publik dilakukan oleh pegawai birokrasi (Pegawai Negeri Sipil) yang berkinerja baik. Indiahono (2009:232) mengatakan birokrasi yang profesional atau berkinerja baik adalah birokrasi yang produktif, berkualitas, responsif, responsibel dan akuntabel. Namun realita yang terjadi setelah reformasi birokrasi (ditetapkannya Undang-Undang Republik Indonesia Nomor 5 Tahun 2014 tentang Aparatur Sipil Negara) tidak berbeda dengan sebelumnya sehingga dapat dikatakan bahwa kinerja Pegawai Negeri Sipil masih mengalami fenomena yang sama yaitu, kinerja Pegawai Negeri Sipil di Indonesia masih cukup rendah, (Kompas.com: 12 November 2014;
9 Juli 2015; Kompasiana.com, 02 September 2015; Media Indonesia.com: 16 Juni 2016). Hal yang sama terjadi juga di Nusa Tenggara Timur, (Pos Kupang.com: 28 Pebruari 2015; 20 Juni 2015; 14 November 2015; 16 Desember 2015; 8 Desember 2016).

Kinerja pegawai yang optimal merupakan obsesi yang selalu diupayakan pencapaiannya oleh setiap organisasi baik swasta maupun instansi pemerintah dalam era pesaingan yang kompetitif. Hal ini logis, mengingat kinerja pegawai yang optimal merupakan kunci keberhasilan atau pondasi kinerja organisasi secara keseluruhan. Menurut Robert dan Jackson (dalam Machfud, dkk., 2015:174); Mathis dan Jackson (dalam Yunus, 2012:372) kinerja organisasi pada dasarnya adalah apa yang dilakukan atau tidak dilakukan oleh pegawai dalam lingkungan organisasi. Sedarmayanti (2007:319) mengatakan manusia merupakan faktor paling menentukan dalam setiap organisasi, termasuk dalam hal ini birokrasi pemerintahan yang diawaki sumber daya aparaturnya sebagai birokrat. Birokrat sebagai salah satu unsur kekuatan daya saing bangsa, bahkan sebagai penentu utamanya, harus memiliki kompetensi dan kinerja tinggi demi pencapaian tujuan, tidak saja profesionalitas dan pembangunan citra pelayanan publik, tetapi juga sebagai perekat pemersatu bangsa. Jadi apa yang 
dikemukakan oleh Robert dan Jackson; Mathis dan Jackson; serta Sedarmayanti diatas bahwa, sangat penting kinerja pegawai bagi sebuah organisasi dan organisasi dituntut untuk dapat menciptakan, mempertahankan dan meningkatkan kinerja pegawai sehingga kinerja pegawai menjadi optimal dan tercapainya tujuan organisasi. Gibson (dalam Dolphina, 2012:1) mengemukakan bahwa, kinerja organisasi tergantung dari kinerja individu atau dengan kata lain kinerja individu akan memberikan kontribusi pada kinerja organisasi. Hal ini menuntut organisasi baik swasta maupun instansi pemerintah untuk selalu berusaha menemukan cara dan kebijakan yang efektif untuk meningkatkan kinerja pegawainya agar optimal sehingga tercapainya kinerja organisasi. Penelitian Rizkansyah, dkk. (2015); Hasballah, dkk. (2015) menunjukkan bahwa kinerja pegawai berpengaruh terhadap kinerja organisasi.

Tresiana (2015:166) mengatakan bahwa, kesejahteraan dan pelayanan publik merupakan hak dasar warga dan sebagai kewajiban yang melekat dalam kelembagaan dan aparatur publik, tanpa terkecuali mulai dari level nasional sampai pada tataran street level bureaucracy tingkat Kelurahan, bahkan RT (Rukun Tetangga). Kemudian Tresiana menambahkan, peningkatan kesejahteraan dan pelayanan publik yang perlu dimulai dari wilayah desa dan kelurahan, karena merupakan amanah dan sebagai tolak-ukur keberhasilan otonomi daerah. Lebih lanjut Tresiana mengemukakan, kelurahan sebagai home base program, kebijakan pemerintah dan pembangunan; serta disamping itu penyelenggaraan pemerintah pada lingkup kelurahan adalah garda depan yang bersentuhan langsung dengan masyarakat yang akan menentukan kondusivitas penyelenggaraan Pemerintah Kabupaten/Kota. Sehingga kinerja pegawai yang optimal juga merupakan obsesi yang selalu diupayakan oleh pimpinan instansi Kelurahan di Kecamatan Maulafa Kota Kupang, sebab tercapai atau tidaknya tujuan instansi Kelurahan dalam melaksanakan tugas-tugas pelayanan publik ditentukan oleh kinerja pegawai yang bekerja di instansi Kelurahan tersebut. Setiawan (2014:13) menambahkan, kinerja pekerja sangat penting karena hanya dengan kinerja yang baik perusahaan (instansi) akan berkembang. Tidak pernah ada cerita jika kinerja pekerja buruk maka kinerja perusahaan (instansi) menjadi baik. Dalam Sindonews.com (9 November 2012:1) dikatkatakan betapapun komprehensif dan canggih strategi dengan berbagai perencanaan yang telah disusun rapi, akan menjadi sia-sia ketika SDM yang menjalankannya tidak melakukannya dengan benar. Dengan demikian pimpinan instansi Kelurahan di Kecamatan Maulafa harus menemukan cara dan kebijakan yang efektif untuk meningkatkan kinerja pegawai agar optimal sehingga tercapainya tujuan instansi Kelurahan. Penelitian yang dilakukan oleh Mariadi, dkk. (2015); Muliana, dkk. (2015) menemukan bahwa, kinerja pegawai berpengaruh signifikan terhadap kinerja instansi.

Telah dikemukakan diatas bahwa kinerja pegawai penting bagi organisasi-organisasi termasuk instansi Kelurahan di Kecamatan Maulafa, namun berdasarkan hasil penelitian, wawancara dan observasi yang dilakukan peneliti, keadaan yang terjadi adalah kinerja pegawai Kelurahan di Kecamatan Maulafa belum terwujud seperti yang diharapkan. Hal ini terlihat dari pegawai yang melaksanakan pekerjaan jika diperintah atasan, pekerjaan yang pelaksanaannya tertunda, pekerjaan yang diselesaikan tidak tepat waktu, tepat mutu dan pegawai yang sering terlambat masuk kantor serta pegawai karena tidak ada pengawasan dan salah satu bentuk pegawasan terhadap kehadiran pegawai adalah absen sidik jari (finger print), pegawai yang tidak saling mendukung satu sama lain dalam menyelesaikan pekerjaan.

Kinerja pegawai sangat ditentukan atau dipengaruhi oleh beberapa faktor/variabel, antara lain: (Mangkunegara, 2013:67; Robbins dalam Molan, 2007:241; Gibson, dkk. dalam Wahyudi, 2011:69) kemampuan (A) dan motivasi (M) atau $(\mathrm{P})=\mathrm{f}(\mathrm{A} \times \mathrm{M})$. Grifin (dalam Sule dan Saefullah, 2005:235); Sopiah (2008:23) menambahkan bahwa, kinerja terbaik ditentukan oleh 3 faktor, yaitu: 1) motivasi kerja; 2) kemampuan kerja; dan 3) lingkungan kerja. Sedangkan Jones (dalam Rahadi, 2010:5) mengatakan bahwa Banyak hal yang menyebabkan terjadinya kinerja yang buruk, antara lain: 1) kemampuan pribadi; 2) kemampuan manajer; 3) kesenjangan proses; 4) masalah lingkungan; 5) situasi pribadi; dan 6) motivasi. Kemudian Porter dan Lawler (dalam Yuwono, dkk., 2006:289) mengatakan bahwa, penting untuk memahami peran-peran variabel psikologis lainnya seperti efikasi diri dalam hubungan usaha (motivasi) dengan kinerja. Lebih lanjut Robbins (dalam Molan, 2007:229) mengatakan bahwa, 3 faktor lain yang telah ditemukan dapat mempengaruhi hubungan antara sasaran dengan kinerja yaitu: komitmen sasaran, keefektifan diri (self efficacy) yang memadai dan budaya nasional.

Didalam penelitian ini peneliti menggunakan: kemampuan kerja $\left(\mathrm{X}_{1}\right)$ sebagai variabel bebas, kemampuan adalah sifat yang 
dibawa lahir atau dipelajari yang memungkinkan seseorang menyelesaikan pekerjaan, (Gibson, dkk. dalam Abdulkarim, 2016:152). Sesuai dengan penelitian yang dilakukan Widyaningrum (2012); Wirmayanis (2014); Putri, dkk. (2015); Abdulkarim (2016) membuktikan bahwa kemampuan kerja berpengaruh positif dan signifikan terhadap kinerja pegawai. Sedangkan hasil berbeda diketahui dari penelitian peneliti Triswanto dan Triyanto (2016) menunjukkan bahwa kemampuan kerja berpengaruh secara negatif dan signifikan terhadap kinerja pegawai. Lebih lanjut penelitian Kontu, dkk. (2015); Widyastuti, dkk. (2017) menyatakan bahwa kemampuan kerja berpengaruh tidak signifikan terhadap kinerja.

Motivasi kerja $\left(\mathrm{X}_{2}\right)$ menurut Lindner (dalam Jansen dan Samuel, 2014:53) motivasi adalah "the inner force that drives individuals to accomplish personal and organizational Goals" (kekuatan batin yang mendorong individu untuk mencapai tujuan pribadi dan organisasi). Lebih lanjut penelitian yang dilakukan oleh Jayaweera (2015); Heliawan (2016); Nurcahyani \& Adnyani (2016); Laan (2016) motivasi kerja berpengaruh positif dan signifikan terhadap kinerja. Penelitian Setiawan (2015) motivasi berpengaruh signifikan terhadap kinerja karyawan. Sedangkan penelitian Wijayanti dan Meftahudin (2016) menunjukkan bahwa motivasi kerja berpengaruh negatif terhadap kinerja karyawan. Penelitian Sudarmo dan Lukita (2015) motivasi berpengaruh negatif dan tidak signifikan terhadap kinerja karyawan

Lingkungan kerja $\left(Z_{1}\right)$ sebagai variabel moderator. Menurut Sumarsono (2009:30); Nawawi (2012:440); Sunyoto (2012:43) lingkungan kerja adalah segala sesuatu yang ada disekitar pegawai, yang langsung atau tidak langsung mempengaruhi dirinya dalam menjalankan tugas-tugas yang dibebankan. Penelitian Imran, dkk. (2012); Sofyan (2013); Emeka dan Eyuche (2014); Rokhilah dan Darmanto (2014); Pratama (2015); Suwondo dan Sutanto (2015) menunjukan bahwa lingkungan kerja berpengaruh positif dan signifikan terhadap kinerja pegawai. Sedangkan penelitian Mamangkey, dkk. (2015) menunjukkan bahwa lingkungan kerja berpengaruh negatif terhadap kinerja karyawan; Penelitian Hanafi dan Yohana (2017); lingkungan kerja tidak berpengaruh dan signifikan terhadap kinerja karyawan. Rahmayanti dan Afandi (2014); Fadillah, dkk. (2017) lingkungan kerja berpengaruh tidak signifikan terhadap kinerja karyawan

Efikasi diri/self efficacy $\left(Z_{2}\right)$ juga sebagai variabel moderator. Menurut John P. (dalam
Sundari, 2016:28) efikasi diri merupakan keyakinan akan kemampuan diri dalam menguasai suatu situasi dan menghasilkan akhir yang diinginkan. Penelitian Cherian dan Jacob (2013); Liana, dkk. (2016) dikatakan bahwa Self-efficacy berpengaruh positif terhadap kinerja. Lebih lanjut penelitian Adianita, dkk. (2017) Self-efficacy berpengaruh signifikan terhadap kinerja karyawan. Sedangkan hasil berbeda diungkapkan dalam penelitian Kaseger (2013) bahwa Selfefficacy berpengaruh tidak signifikan terhadap kinerja karyawan. Lebih lanjut penelitian Gultom (2016) menjelaskan bahwa self efficacy berpengaruh negatif terhadap kinerja auditor.

Didalam penelitian ini peneliti menggunakan lingkungan kerja sebagai variabel moderator karena lingkungan adalah variabel yang bersifat situasional. Menurut Robbins (dalam Molan, 2007:16) bahwa faktor-faktor situasional adalah variabel-variabel yang memoderatkan hubungan (pengaruh) antara dua atau lebih variabel dan memperbaiki korelasi (pengaruh). Setiap pegawai pasti berinteraksi dengan lingkungan kerjanya sehingga lingkungan kerja akan mempengaruhi perilaku pegawai dalam bekerja. Sebagaimana yang dikatakan Davis (dalam Rochman, 2008:21-22) bahwa, lingkungan dalam suatu organisasi mempunyai arti penting bagi individu yang bekerja didalamnya, karena lingkungan kerja akan mempengaruhi secara langsung maupun tidak langsung manusia (pegawai) yang ada didalamnya. Demikian juga efikasi diri (self efficacy) sebagai variabel moderator karena efikasi diri adalah suatu keyakinan/persepsi seorang pegawai mengenai seberapa jauh pegawai tersebut mampu menyelesaikan pekerjaan dalam situasi tertentu. sehingga efikasi diri juga bersifat situasional dan efikasi diri juga sebagai variabel yang secara teoritis dinyatakan sebagai variabel moderator (di dalam teori/model penetapan tujuan, Locke dan Latham dalam Yuwono, dkk., 2006:575). Sedangkan kemampuan tidak dapat dijadikan variabel moderator karena kemampuan adalah kapasitas yang dimiliki oleh pegawai dalam melaksanakan pekerjaannya sehingga kemampuan bukan bersifat situasional namun merupakan suatu keharusan yang harus dimiliki oleh pegawai dan yang diharapkan oleh manajemen (dalam praktik manajemen sumber daya manusia yaitu seleksi, rekrutmen, dll) atau dengan kata lain kemampuan sebagai variabel individual. Demikian juga motivasi tidak dapat dijadikan sebagai variabel moderator dalam penelitian ini karena motivasi adalah himpunan kekuatan (baik internal maupun eksternal) atau sesuatu yang mendorong seseorang 
untuk berperilaku. Motivasi juga bukan bersifat situasional tetapi akibat dari situasional. Sehingga tanpa adanya kemampuan dan motivasi, pegawai tidak akan mencapai kinerja atau tujuan yang diinginkan atau dengan kata lain kemampuan dan motivasi merupakan hal yang utama dan penting yang harus dimiliki oleh seorang pegawai serta kedua variabel ini tidak dapat dipisahkan satu sama lain. Seperti yang dikatakan oleh As'ad (dalam Hanafi dan Yohana, 2017:78) bahwa, pendekatan teori atribusi atau expectancy theory mengenai kinerja dirumuskan $\mathrm{P}=\mathrm{M} \times \mathrm{A}$ kinerja atau kinerja adalah hasil dari interaksi antara motivasi dan ability sehingga motivasi dan kemampuan tidak dapat dipisahkan dari seorang pegawai. Lebih lanjut Wahyudi (2011:69) mengatakan bahwa, kemampuan mencerminkan kesanggupan seseorang untuk melaksanakan tugas dan motivasi mencerminkan bagaimana seseorang dengan penuh semangat menerapkan kemampuan itu. Seseorang yang mempunyai kemampuan dan motivasi tertentu apabila dipadukan maka hasil kerjanya akan nampak pada performansi kerja (kinerja) dalam bentuk efektivitas kerja. Sedangkan kinerja pegawai tidak dapat dijadikan sebagai variabel moderator karena kinerja pegawai adalah tujuan yang ingin dicapai atau sasaran akhir dari tercapai/tidaknya kinerja organisasi dan tujuan reformasi birokrasi, atau dengan kata lain kinerja merupakan sasaran akhir dalam praktik manajemen sumber daya manusia dan perilaku pegawai di dalam instansi atau organisasi. Yunus (dalam Yunus, 2012:370) menambahkan bahwa, kinerja merupakan hal penting yang dibutuhkan dalam rangka menunjang pencapaian tujuan perusahaan (instansi).

Keadaan yang terjadi terkait kemampuan kerja, motivasi kerja dan lingkungan kerja serta efikasi diri yang terjadi pada instansi Kelurahan di Kecamatan Maulafa Kota Kupang dapat diuraikan sebagai berikut: Persoalan kemampuan kerja pegawai yang terjadi adalah pegawai yang kurang mengikuti pelatihan terkait tugas yang diemban, pegawai sering menyelesaikan pekerjaan yang melebihi waktu yang ditentukan, pegawai yang kurang teliti dalam menyelesaikan pekerjaan sehingga terjadi kesalahan sehingga dapat dikatakan pegawai kurang profesional; persoalan motivasi kerja pegawai yang terjadi adalah: pegawai yang sering pulang lebih awal dari waktu yang ditentukan, gaji yang belum dapat memenuhi kebutuhan hidup pegawai, pegawai yang kurang mendapatkan penghargaan atas kinerja yang dicapai sehingga pegawai kurang termotivasi; persoalan lingkungan kerja pegawai yang terjadi adalah: bunyi bising di dalam ruangan kerja, ruangan kerja yang sempit atau ruang kerja yang kurang nyaman, cahaya yang terlalu silau dan hubungan pegawai yang kurang harmonis (baik dengan rekan kerja maupun dengan atasan). Serta persoalan efikasi diri adalah pegawai tidak mau/jarang mengerjakan pekerjaan-pekerjaan yang sulit sedangkan pekerjaan yang sulit/sukar dan spesifik akan selalu menghantar ke kinerja yang lebih tinggi, sering gagal atau sering melihat orang lain gagal dalam melaksanakan pekerjaan yang sulit dan kurang percaya diri atau dengan kata lain pegawai kurang efikasi diri. Hal-hal tersebut diatas yang menyebabkan kinerja pegawai yang tidak sesuai dengan harapan instansi Kelurahan dan tujuan reformasi birokrasi.

Penelitian ini diharapkan dapat melihat secara jelas, aktual dan faktual mengenai kemampuan kerja dan motivasi kerja yang dimoderator lingkungan kerja serta efikasi diri dalam mendukung kinerja pegawai agar optimal sehingga tercapainya tujuan instansi kelurahan dan berimplikasi pada tujuan reformasi birokrasi, serta penelitian ini untuk membuktikan inkonsistensi hasil-hasil penelitian diatas yang bermanfaat bagi perkembangan ilmu pengetahuan terutama dalam bidang ilmu sumber daya manusia dan terlebih khususnya mengenai pengaruh kemampuan kerja dan motivasi kerja terhadap kinerja pegawai dengan lingkungan kerja dan efikasi diri sebagai variabel moderator.

\section{KAJIAN LITERATUR}

\section{Pengaruh Kemampuan Kerja terhadap Kinerja Pegawai}

Semakin tinggi tingkat kemampuan kerja yang dimiliki oleh seorang karyawan, maka kinerja karyawan di dalam perusahaan (instansi) akan tinggi pula, Robbins (dalam Farlen 2011:17). Purba (dalam Siburian, 2014:259) menjelaskan bahwa kinerja individual dipengaruhi oleh kemampuan individu dalam melakukan inovasi. Robbins (dalam Molan, 2007:70) mengatakan bahwa, kemampuan langsung mempengaruhi tingkat kinerja dan kepuasan karyawan lewat kecocokan/kesesuaian antara jabatan dengan kemampuan atau kemampuan dengan pekerjaan. Kemampuan kerja adalah variabel memiliki peran dalam rangka peningkatan kinerja karyawan, (Ismiyanto dan Riyadi, 2014:154). Sesuai dengan penelitian yang dilakukan oleh Widyaningrum (2012) dengan hasil, kemampuan berpengaruh secara signifikan terhadap Kinerja karyawan. Penelitian Nusaku, dkk. (2014) menyatakan 
bahwa, kemampuan memiliki pengaruh yang dominan terhadap kinerja pegawai.

\section{Pengaruh Motivasi Kerja terhadap Kinerja Pegawai}

Gibson, dkk. (dalam Ichyaudin, 1997:340) mengatakan bahwa, kinerja seseorang yang dinilai tidak memuaskan, sering disebabkan oleh motivasi yang rendah. Lebih lanjut dikatakan bahwa, motivasi melibatkan keinginan seseorang untuk menunjukkan kinerja. Dari pernyataan ini, dapat dikatakan bahwa peningkatan motivasi dalam diri seorang karyawan pada suatu perusahaan (instansi) sangat penting untuk mencapai kinerja yang optimal sehingga mencapi tujuan perusahaan. Sesuai dengan hasil penelitian Husaini, dkk. (2014); Jayaweera (2015); Laan (2016) menunjukkan bahwa, motivasi berpengaruh positif dan signifikan terhadap kinerja pegawai.

\section{Pengaruh Lingkungan Kerja terhadap Kinerja Pegawai}

Davis (dalam Rochman, 2008:21-22) menyatakan bahwa, lingkungan kerja dalam suatu organisasi mempunyai arti penting bagi individu yang bekerja di dalamnya, karena lingkungan ini akan mempengaruhi secara langsung maupun tidak langsung manusia yang ada di dalamnya. Penelitian yang dilakukan Rosa (2015); Rumengan dan Mekel (2015); Handayani (2016) menemukan bahwa, lingkungan kerja berpengaruh signifikan terhadap kinerja karyawan/pegawai.

\section{Pengaruh Efikasi Diri terhadap Kinerja Pegawai}

Bidang-bidang yang dapat diterapkan lingkup efikasi diri diantaranya adalah untuk studi dan aplikasi perilaku organisasi dan kinerja di tempat kerja, (Luthans dalam Yuwono, dkk. 2006:337). Orang-orang dengan efikasi diri atau keefektifan diri (self efficacy) yang rendah lebih besar kemungkinan untuk mengurangi upaya mereka atau sama sekali menyerah sedangkan mereka dengan efikasi diri atau keefektifan diri (self efficacy) yang tinggi akan berusaha lebih keras untuk menguasai tantangan itu, (Robbins dalam Molan, 2007:229). Sedangkan Bandura (dalam Yuwono, dkk., 2006:340); Bandura (dalam Kaswan, 2013:93) menekankan bahwa efikasi diri juga memainkan peranan vital dalam mempengaruhi kinerja individu. Penelitian Sulaiman, dkk. (2014) self efficacy berpengaruh positif dan signifikan terhadap kinerja karyawan. Sesuai dengan penelitian Murniningsih, dkk. (2013) terdapat pengaruh yang signifikan dan positif efikasi diri terhadap kinerja. Selanjutnya Hasil penelitian Beattie, dkk. (2016) mengkonfirmasi bahwa umpan balik merupakan moderator penting dari hubungan self efficacy - kinerja. Penelitian Liana dkk. (2016) menunjukkan self efficacy berpengaruh positif terhadap kinerja guru.

\section{Pengaruh Kemampuan Kerja terhadap Kinerja Pegawai yang dimoderasi Lingkungan Kerja}

Ketidaknyamanan dari lingkungan kerja yang dialami oleh karyawan (pegawai) bisa berakibat fatal yaitu menurunnya kinerja dari karyawan (pegawai) itu sendiri, (Susilaningsih dalam Novyanti, 2015:105). Lebih lanjut Gibson (dalam Sitohang, dkk., 2012:339) menegaskan bahwa, selain manusia, lingkungan kerja termasuk sebagai variabel sumber daya dalam lingkungan oganisasi yang berperan penting dalam mendukung perilaku kerja sehingga kinerja para karyawan dapat ditingkatkan. Penelitian yang dilakukan oleh Emeka dan Eyuche (2014) menyimpulkan bahwa faktor tempat kerja (lingkungan kerja) memainkan peran positif dan signifikan terhadap kinerja karyawan. Lebih lanjut penelitian yang dilakukan oleh Suwondo dan Sutanto (2015); Pratama (2015) menunjukkan bahwa lingkungan kerja berpengaruh terhadap kinerja. Serta penelitian yang dilakukan oleh Ismiyanto dan Riyadi (2014) menjelaskan bahwa kemampuan kerja merupakan variabel yang paling besar pengaruhnya terhadap kinerja karyawan. Indikator yang paling dominan dari kemampuan kerja adalah kursus atau pelatihan. Demikian pula lingkungan kerja juga merupakan variabel yang berpengaruh dominan kedua terhadap kinerja karyawan. Indikator hubungan sesama karyawan merupakan indikator yang paling tinggi konstribusinya terhadap lingkungan kerja. Sehingga dapat dikatakan semakin tinggi kemampuan kerja yang dimiliki oleh seorang pegawai, maka kinerja pegawai di dalam instansi akan tinggi pula namun harus didukung oleh lingkungan kerja yang kondusif, karena lingkungan kerja secara langsung maupun tidak langsung mempengaruhi pegawai yang ada didalamnya. 


\section{Pengaruh Motivasi Kerja terhadap Kinerja Pegawai yang dimoderasi Lingkungan Kerja}

Ermayanti (dalam Husaini, 2014:76) mengemukakan bahwa pemahaman motivasi, baik yang ada dalam diri karyawan maupun yang berasal dari lingkungan akan dapat membantu dalam peningkatan kinerja. Sunyoto (2012:43) menambahkan bahwa, lingkungan kerja merupakan bagian komponen yang sangat penting di dalam karyawan (pegawai) melakukan aktivitas kerja. Dengan memperhatikan lingkungan kerja yang baik atau menciptakan kondisi kerja yang mampu memberikan motivasi untuk bekerja. Penelitian Rahmayanti dan Afandi (2015) dikatakan bahwa, tidak terdapat pengaruh positif dari variabel motivasi $\left(\mathrm{X}_{2}\right)$ terhadap kinerja karyawan (Y) serta tidak terdapat pengaruh positif dari variabel lingkungan Kerja $\left(\mathrm{X}_{3}\right)$ terhadap kinerja karyawan (Y). Penelitian Sumantri (2016) menunjukkan bahwa, motivasi dan lingkungan kerja berpengaruh signifikan terhadap kinerja karyawan baik secara parsial maupun simultan. Demikian juga penelitian yang dilakukan Praptiestrini (2016) diketahui bahwa, lingkungan kerja berpengaruh signifikan terhadap motivasi kerja.

\section{Pengaruh Kemampuan Kerja terhadap Kinerja Pegawai yang dimoderasi Efikasi Diri}

Makin tinggi efikasi diri atau keefektifan diri (self efficacy) anda makin besarlah kepercayaan diri anda terhadap kemampuan untuk berhasil dalam tugas tertentu, (Robbins dalam Molan, 2007:229). "Seeing people similar to oneself succeed by perseverant effort raises observers' aspirations and beliefs in their own capabilities" (melihat orang yang mirip dengan diri sendiri berhasil dengan upaya gigih yang menimbulkan aspirasi dan keyakinan pengamat dalam kemampuan mereka sendiri), Bandura (2012:13). Penelitian yang dilakukan oleh Ratnaningsih (2016) menunjukkan bahwa, kontribusi antara efikasi diri terhadap kemampuan berpikir kritis matematis sebesar 17,22\%. Kemudian penelitian Cherian dan Jacob (2013) dikatakan bahwa, kinerja karyawan secara positif dipengaruhi oleh keseluruhan self-efficacy. Penelitian Rimper dan Kawet (2014) menunjukkan bahwa, self efficacy berpengaruh secara positif dan signifikan terhadap kinerja karyawan. Lebih lanjut dalam penelitian Elvera (2016) diketahui bahwa, self-eficacy berpengaruh signifikan terhadap kinerja karyawan. Sedangkan dari hasil penelitian Khojasteh, dkk. (2016) menunjukkan bahwa, tidak ada hubungan yang signifikan antara efikasi diri menulis siswa dengan kinerja tulisan mereka.

\section{Pengaruh Motivasi Kerja terhadap Kinerja Pegawai yang dimoderasi Efikasi Diri}

Salah satu faktor yang mempengaruhi hubungan sasaran dengan kinerja adalah efikasi diri atau keefektifan diri (self efficacy) yang memadai, (Robbins dalam Molan, 2007:229). Lebih lanjut dikatakan bahwa, Individu yang tinggi efikasi diri atau keefektifan dirinya tampak menanggapi umpan balik yang negatif dengan meningkatkan upaya dan motivasi. Menurut Azwar (dalam Parasara dan Surya, 2016:3223) tinggi rendahnya selfefficacy yang dipersepsikan akan memotivasi individu secara kognitif untuk bertindak lebih persisten dan terarah, terutama apabila tujuan yang hendak dicapai lebih jelas. Lebih lanjut Slameto (dalam Parasara dan Surya, 2016:3224) mengatakan bahwa, keberhasilan seseorang dalam menyelesaikan tugas atau tantangan yang sulit dapat menyebabkan meningkatnya self-efficacy yang berpengaruh pada motivasi yang lebih kuat terhadap tantangan atau tugas tersebut. Penelitian Kaseger (2013) self-efficacy berpengaruh terhadap kinerja karyawan. Demikian juga penelitian yang dilakukan Parasara dan Surya (2016) menunjukkan bahwa self effcacy berpengaruh positif dan signifikan terhadap motivasi. Kemudian penelitian Marliani (2016) menunjukkan bahwa, motivasi berpengaruh terhadap kinerja karyawan.

Berbagai pandangan terkait pengaruh kemampuan kerja, motivasi kerja, lingkungan kerja, efikasi diri dan kinerja pegawai diatas, dapat digambarkan sebagai berikut:

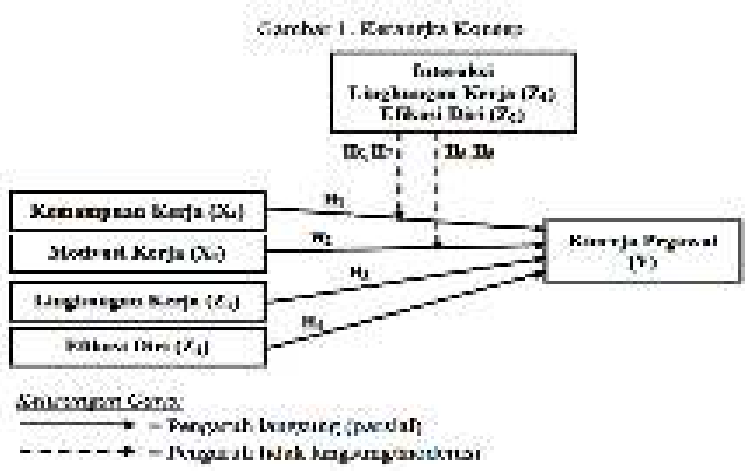




\section{HIPOTESIS PENELITIAN}

Hipotesis yang digunakan peneliti berdasarkan rumusan masalah dalam penelitian ini yaitu:

1. Kemampuan kerja berpengaruh signifikan terhadap kinerja pegawai Kelurahan di Kecamatan Maulafa Kota Kupang.

Kriteria pengujian Hipotesis

2. Motivasi kerja berpengaruh signifikan terhadap kinerja pegawai Kelurahan di Kecamatan Maulafa Kota Kupang.

3. Lingkungan kerja berpengaruh signifikan terhadap kinerja pegawai Kelurahan di Kecamatan Maulafa Kota Kupang.

4. Efikasi diri berpengaruh signifikan terhadap kinerja pegawai Kelurahan di Kecamatan Maulafa Kota Kupang.

5. Kemampuan kerja berpengaruh signifikan terhadap kinerja pegawai Kelurahan di Kecamatan Maulafa Kota Kupang dengan lingkungan kerja sebagai variabel moderasi.

6. Motivasi kerja berpengaruh signifikan terhadap kinerja pegawai Kelurahan di Kecamatan Maulafa Kota Kupang dengan lingkungan kerja sebagai variabel moderasi.

7. Kemampuan kerja berpengaruh signifikan terhadap kinerja pegawai Kelurahan di Kecamatan Maulafa Kota Kupang dengan efikasi diri sebagai variabel moderasi.

8. Motivasi kerja berpengaruh signifikan terhadap kinerja pegawai Kelurahan di Kecamatan Maulafa Kota Kupang dengan efikasi diri sebagai variabel moderasi.

\section{INDIKATOR DAN SKALA PENGUKURAN.}

\section{Kemampuan Kerja} Indikator kemampuan kerja adalah:

Pendidikan; Pelatihan; Pengetahuan; Keterampilan; dan Pengalaman, (Wahyuningrum, 2008:49; Deierlein dan Bob \& Dessler dalam Zainullah, dkk., 2012:127; Wirmayanis, 2014:214).

2. Motivasi Kerja Indikator motivasi kerja adalah: Kebutuhan Fisiologis; Kebutuhan rasa aman; Kebutuhan Sosial; Kebutuhan Harga Diri; dan Kebutuhan Aktualisasi Diri, (Maslow dalam Mangkunegara, 2013:94).

3. Lingkungan Kerja Indikator lingkungan kerja adalah: Hubungan karyawan (pegawai); Tingkat kebisingan lingkungan kerja; Peraturan Kerja; Penerangan; Sirkulasi Udara; dan Keamanan, (Sunyoto, 2013:44-47).

4. Efikasi Diri
Indikator efikasi diri adalah: Pengalaman Penguasaan atau Pencapaian Kinerja; Pengalaman Pribadi dan Pemodelan; Persuasi Sosial; dan Peningkatan Fisik dan Psikologi, (Bandura, 2012:12; Luthans dalam Yuwono, dkk., 2006:343).

5. Kinerja Pegawai

Indikator kinerja pegawai adalah: Kualitas Pekerjaan; Kuantitas Pekerjaan; Ketepatan Waktu; Efektivitas Biaya; Kebutuhan akan Pengawasan; Dampak Interpersonal; Kehadiran; dan Kemampuan bekerja sama, (Rahadi, 2010:9; Mangkunegara, 2013:67; Bernadin dan Russell dalam Rahadi, 2010:34$35)$.

Keseluruhan variabel diukur menggunakan skala likert. Sugiyono (2013:93-94) mengatakan bahwa, untuk keperluan analisis kuantitatif, maka jawaban itu dapat diberi skor, misalnya:

a. Sangat setuju diberi skor 5

b. Setuju diberi skor 4

c. Ragu-ragu diberi skor 3

d. Tidak setuju diberi skor 2

e. Sangat tidak setuju diberi skor 1

\section{POPULASI DAN SAMPEL}

\section{Populasi}

Populasi dalam penelitian ini adalah pegawai Kelurahan di Kecamatan Maulafa Kota Kupang yang terdiri dari 9 instansi Kelurahan dengan jumlah 118 pegawai.

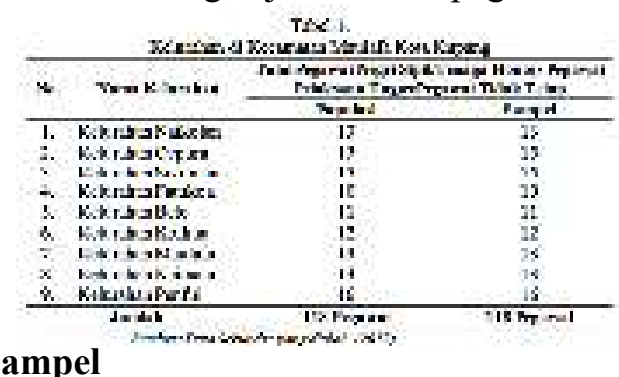

Sampel adalah bagian dari jumlah dan karateristik yang dimiliki oleh populasi tersebut, (Sugiyono, 2013:81). Dalam penelitian ini, teknik pengambilan sampel yang digunakan adalah teknik total sampling atau teknik sensus. Sensus adalah kelompok data penelitian yang dikategorikan untuk mencatat seluruh elemen penelitian sebagai subjek penelitian tanpa kecuali, (Suharso, 2009:57). Sehingga sampel yang digunakan dalam penelitian ini adalah seluruh Pegawai Negeri Sipil Kelurah di Kecamatan Maulafa Kota Kupang yaitu sebanyak 118 pegawai.

\section{ALAT ANALISIS}

Alat analisis yang digunakan dalam penelitian ini adalah MRA. 


\section{PENYEBARAN KUESIONER}

Kuesioner yang disebarkan pada pegawai Kelurahan di Kecamatan Maulafa sebanyak 117 eksemplar dari 118 sampel karena pada kelurahan Naimata terdapat 1 pegawai yang dimutasi. Dari 117 eksemplar kuesioner yang dibagikan sebanyak 81 eksemplar dikembalikan atau sebesar $69,23 \%$, namun kuesioner yang diisi lengkap hanya sebanyak 66 eksemplar atau 56,41\% sehingga kuesioner yang layak dianalisis sebanyak 66 eksemplar.

\section{HASIL DAN PEMBAHASAN}

\section{UJI FIT MODEL}

Ghozali (2014:39) mengatakan bahwa untuk menilai fit model dalam penelitian menggunakan metode SEM-PLS memerlukan dua tahapan yaitu: model pengukuran (outer model) dan model struktural (inner model).

a. Model Pengukuran (Outer Model)

Analisa Outer Model ini menspesifikasi hubungan antar variabel laten dengan indikator-indikatornya atau dapat dikatakan bahwa outer model mendefinisikan bagaimana setiap indikator berhubungan dengan variabel latennya. Outer model dinilai dengan cara melihat nilai Convergent validity (besarnya loading faktor untuk masing-masing indikator). Ukuran reflektif dikatakan tinggi jika berkorelasi lebih dari 0,70 dengan konstruk yang ingin diukur. Namun demikian untuk penelitian tahap pengembangan skala pengukuran nilai loading 0,50 sampai 0,60 dianggap cukup, (Ghozali, 2014:61).

Berikut merupakan hasil PLS Algoritma tahap pertama berdasarkan output SmartPLS 3 .

Gambar 2. Hasil PLS Algoritma Tahap Pertama berdasarkan output SmartPLS 3

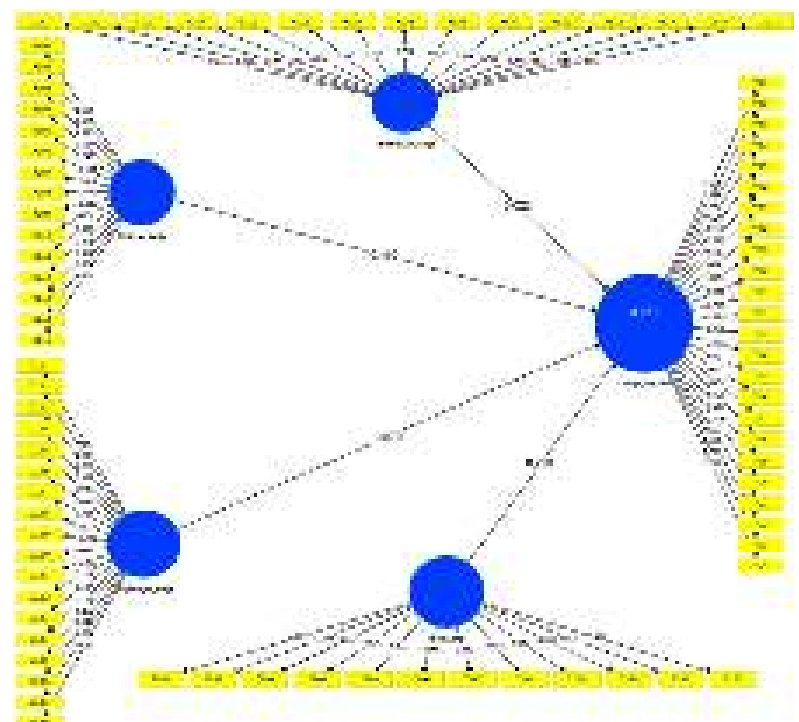

Dari gambar 2 di atas, dapat dilihat bahwa nilai convergent validity dengan loading factor untuk variabel kemampuan kerja (X1) terdapat dua indikator yang nilainya lebih dari 0.70 yaitu: indikator $\mathrm{x} 1.07=0.858$ dan $\mathrm{x} 1.08=$ 0.816; variabel motivasi kerja (X2) terdapat dua indikator yaitu $\mathrm{x} 2.05=0.814$ dan $\mathrm{x} 2.15=0.858$; variabel lingkungan kerja (Z1) terdapat empat indikator yaitu z1.02 $=0,844, \mathrm{z} 1.03=0,816$, z1.07 = 0,757 dan z1.08 = 0,835; variabel efikasi diri (Z2) terdapat lima indikator yaitu $\mathrm{z} 2.01=$ $0,718, \mathrm{z} 2.03=0,773, \mathrm{z} 2.05=0,828, \mathrm{z} 2.08=0,826$ dan $\mathrm{z2} .10=0,762$; variabel kinerja pegawai $(\mathrm{Y})$ terdapat sembilan indikator yaitu y. $03=0,811$, у. $04=0,745$, у. $05=0,771$, у. $07=0,710$, у. $09=$ 0,740, y. $12=0,787$, у. $18=0,730$, y. $23=0,800$ dan y.24 $=0,724$. Indikator- indikator tersebut yang dapat digunakan untuk pengujian selanjutnya. Sebagaimana disajikan pada gambar berikut.

Gambar 3. Hasil PLS Algoritma Tahap Kedua (indikator-indikator yang dapat dilanjutkan ke pengujian berikut)

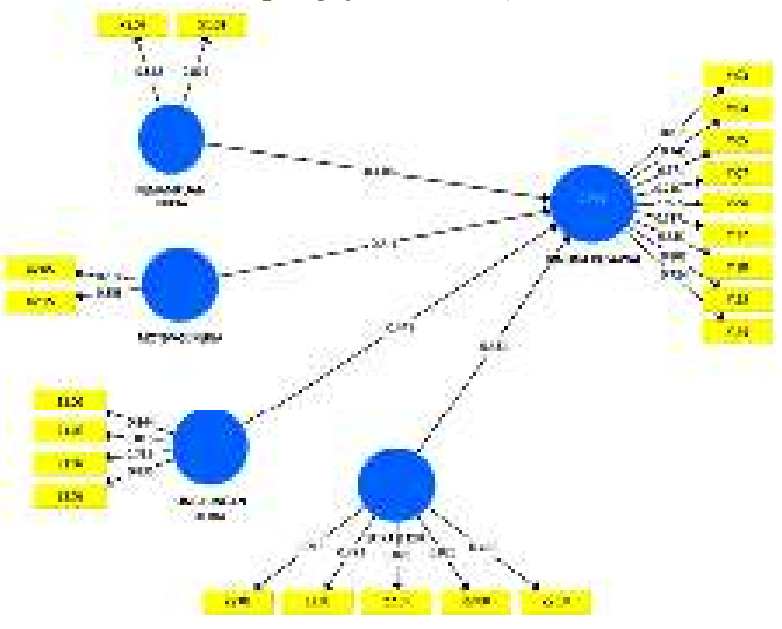

Setelah nilai convergent validity telah memenuhi kriteria yang ditetapkan, maka tahap selanjutnya adalah melihat nilai composite reliability dan nilai cronbach's alpha. Nilai yang diharapkan untuk composite reliability 0,70 dan cronbach's alpha adalah 0.50 . Pada tabel berikut menunjukkan hasil construct reliability and validity dari ke semua variabel berdasarkan output SmartPLS 3.

Tabel 2

Construct Reliability and Validity

\begin{tabular}{|c|c|c|c|c|c|}
\hline \multirow[t]{2}{*}{ a Now } & ta cosktividipt & \multirow{2}{*}{ in to } & \multicolumn{2}{|c|}{ (6) Ersinkisty } & \multirow{2}{*}{ 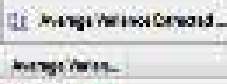 } \\
\hline & insed & & $+\infty=$ & Covonat is. & \\
\hline \multicolumn{2}{|c|}{ movera } & sent & wen & weil & wars \\
\hline \multicolumn{2}{|c|}{ nived avnian, } & $\cos 5$ & $=0$ & ost & siai \\
\hline \multicolumn{2}{|c|}{ 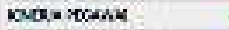 } & ExT & $\operatorname{sen}$ & BSM & 248 \\
\hline \multicolumn{2}{|c|}{ insovaมn } & $\mathrm{mm}$ & she & 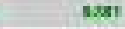 & sent \\
\hline \multicolumn{2}{|c|}{ nenwaries } & $\leq e$ & Lin & aves & 2.12 \\
\hline
\end{tabular}

Dari tabel 2 di atas, dapat dilihat bahwa nilai cronbach's alpha dan composite reliability dari semua variabel sangat baik, 
dikarenakan telah melebihi kriteria yang telah ditentukan, yaitu 0.70 untuk composite reliability masing-masing konstruk di atas 0,70. Disamping itu nilai cronbach's alpha untuk masing-masing konstruk di atas 0,50. Validitas masing-masing konstruk dapat diuji dengan average variance extracted (AVE). Hasil tabel di atas menunjukkan nilai AVE masing-masing konstruk di atas 0,50. Sehingga dapat disimpulkan bahwa indikator-indikator sebagai pengukur variabel laten merupakan pengukur yang valid dan reliabel atau sudah memenuhi kriteria validitas dan reliabilitas.

Selanjutnya untuk mengetahui tingkat signifikansi pengaruh variabel moderasi maka dilakukan calcuate bootstrapping sebagaimana disajikan pada gambar di bawah ini.

Gambar 4. Hasil calcuate bootstrapping Tahap

Pertama berdasarkan output SmartPLS 3

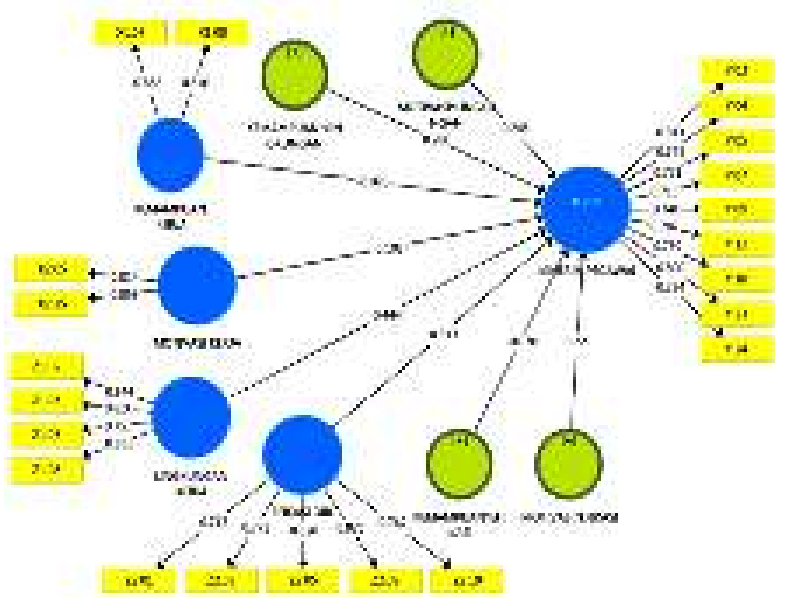

b. Model Struktural (Inner Model)

Model struktural (inner model) digunakan untuk melihat hubungan antara konstruk dan nilai signifikansi serta nilai Koefisien determinasi $\left(\mathrm{R}^{2}\right)$.

Nilai $R$-square dilihat untuk mengukur seberapa besar kontribusi variabel independen yang digunakan terhadap variabel dependen. Nilai $R$-square mempunyai range antara 0 sampai dengan $1\left(0 \leq R^{2} \geq 1\right)$. Pada tabel berikut merupakan nilai dari koefisien determinasi $\left(\mathrm{R}^{2}\right)$ berdasarkan output SmartPLS 3.

Tabel 3. Nilai Koefisien Determinasi (R-square) Kinerja Pegawai

\begin{tabular}{|c|c|c|}
\hline Variabel & R Square & $\begin{array}{c}\text { R Square } \\
\text { Adjusted }\end{array}$ \\
\hline Kinerja Pegawai & 0,799 & 0,770 \\
\hline
\end{tabular}

Dari tabel diatas dapat dilihat bahwa nilai $R$-square dari variabel dependen (kinerja pegawai) adalah sebesar 0,799 dan nilai dari $R$ square Adjusted adalah sebesar 0,770. Hal ini mengindikasikan bahwa model yang digunakan baik.

\section{PENGUJIAN HIPOTESIS}

Setelah mengevaluasi outer model dan inner model, maka tahap selanjutnya dilakukan pengujian hipotesa. Pengujian hipotesa sendiri dilakukan dengan metode bootstrapping yang terdapat di SmartPLS 3. Pada tabel berikut ini merupakan hasil bootstrapping yang menggambarkan hasil estimasi masing-masing variabel dengan taraf signifikansi 5\% (T-Statistik $>1.96$ ) dan nilai probabilitasnya 5\% ( $p$-value $<$ $0.05)$.

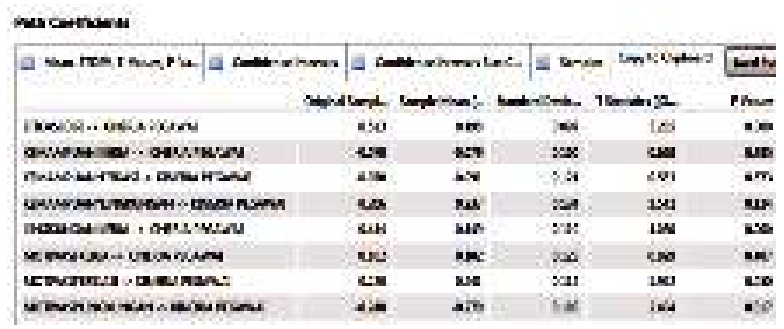

Dari tabel di atas dapat diinterpretasi hasilnya sebagai berikut:

1) Kemampuan kerja berpengaruh tidak signifikan terhadap kinerja pegawai dengan nilai t-statistik sebesar 0,698 dan nilai orginal sample/p-value sebesar 0,485. Dengan demikian maka hipotesis pertama Ha ditolak dan Ho diterima.

2) Motivasi kerja berpengaruh tidak signifikan terhadap kinerja pegawai dengan nilai $t$ statistik sebesar 0,829 dan nilai orginal sample/p-value sebesar 0,407. Dengan demikian maka hipotesis kedua Ha ditolak dan Ho diterima.

3) Lingkungan kerja berpengaruh signifikan terhadap kinerja pegawai dengan nilai tstatistik sebesar 4,030 dan nilai orginal sample/p-value sebesar 0,000 . Dengan demikian maka hipotesis ketiga Ha diterima dan Ho ditolak.

4) Efikasi diri berpengaruh signifikan terhadap kinerja pegawai dengan nilai t-statistik sebesar 5,285 dan nilai orginal sample/p-value sebesar 0,000. Oleh sebab itu, hipotesis keempat $\mathbf{H a}$ diterima dan Ho ditolak.

5) Kemampuan kerja berpengaruh tidak signifikan terhadap kinerja pegawai yang dimoderasi lingkungan kerja dengan nilai tstatistik sebesar 1,542 dan nilai orginal sample/p-value sebesar 0,124. Dengan demikian maka hipotesis kelima Ha ditolak dan Ho diterima.

6) Motivasi kerja berpengaruh signifikan terhadap kinerja pegawai yang dimoderasi lingkungan kerja dengan nilai t-statistik sebesar 2,404 dan 
nilai orginal sample/p-value sebesar 0,017 . Dengan demikian maka hipotesis keenam Ha diterima dan Ho ditolak.

7) Kemampuan kerja berpengaruh tidak signifikan terhadap kinerja pegawai yang dimoderasi efikasi diri dengan nilai t-statistik sebesar 0,563 dan nilai orginal sample/p-value sebesar 0,573. Dengan demikian maka hipotesis ketujuh Ha ditolak dan Ho diterima.

8) Motivasi kerja berpengaruh tidak signifikan terhadap kinerja pegawai yang dimoderasi efikasi diri dengan nilai t-statistik sebesar 1,962 dan nilai orginal sample/p-value sebesar 0,050 . Dengan demikian maka hipotesis kedelapan Ha ditolak dan Ho diterima.

\section{PEMBAHASAN HASIL PENGUJIAN HIPOTESIS}

Berdasarkan hasil analisis pengujian hipotesis diatas, dapat dijelaskan sebagai berikut:

1. Pembahasan Hipotesis ke-1 (kesatu); hasil pengujian hipotesis diatas menunjukkan bahwa, kemampuan kerja berpengaruh tidak signifikan terhadap kinerja pegawai. Dengan nilai t-statistik sebesar 0,698 dan nilai orginal sample/p-value sebesar 0,485. Dengan demikian maka hipotesis kesatu Ha ditolak dan Ho diterima. Dalam hal ini semakin meningkat kemampuan kerja pegawai maka akan semakin meningkat kinerja pegawai. Hasil ini sesuai dengan penelitian yang dilakukan Widyastuti, dkk. (2017) menunjukkan bahwa kemampuan kerja berpengaruh tidak signifikan terhadap kinerja Aparatur. Hasil dalam penelitian ini menunjukkan bahwa ketika pegawai Kelurahan di Kecamatan Maulafa merasa bahwa kemampuan kerja mereka meningkat maka pegawai mulai lalai dan mengabaikan tugas yang dibebankan atau dengan kata lain ketika pegawai merasa bahwa kemampuan kerjanya meningkat maka pegawai tidak perlu melakukan inovasi dalam melaksanakan pekerjaan. Sebagaimana yang dikatakan Purba (dalam Siburian, 2014:259) bahwa kinerja individual dipengaruhi oleh kemampuan individu dalam melakukan inovasi. Hal ini disebabkan pegawai tidak membutuhkan pengawasan karena merasa memahami segala pekerjaan yang diberikan atau menjadi tugasnya; merasa lebih senior dibanding dengan pegawai lain sehingga: pegawai menyelesaikan pekerjaan melebihi waktu yang ditentukan dan kurang teliti dalam menyelesaikan pekerjaan.

Hasil penelitian ini membuktikan bahwa pimpinan atau pengambil keputusan

belum memberikan penguatan dan penghargaan yang sesuai dengan perilaku pegawai dalam menyelesaikan pekerjaan. Pimpinan atau pengambil keputusan dapat menggunakan teori pengukuhan atau penguatan (reinforcement theory) dan teori pengharapan dalam meningkatkan kemampuan kerja pegawai. Berdasarkan teori penguatan pegawai dituntut agar bekerja secara optimal dan konsisten sehingga mencapai kinerja yang optimal karena imbalan yang diberikan pimpinan disesuaikan dengan perilaku pegawai di masa lalu dan bagi pimpinan agar memberikan imbalan yang sesuai dengan kontribusi pegawai pada instansi, (Hasibuan, 2005:238). Lebih lanjut dalam teori pengharapan juga menekankan pentingnya perilaku individu dalam mencapai hasil (menyelesaikan pekerjaan). Konsep utama teori harapan yaitu: perilaku individu adalah fungsi dari tingkat dimana perilaku berperan penting dalam pencapaian beberapa hasil dan evaluasi hasil ini, (Lewin, 1935; Tolman, 1932 dalam Ramli dan Jusoh, 2015:370). Lebih lanjut dikatakan bahwa telah dibuktikan bahwa teori harapan saat diterapkan dengan benar bagi pegawai dalam melaksanakan pekerjaan akan membawa kesuksesan pada perubahan organisasi, (Ramli dan Jusoh, 2015:366). Dengan demikian pemimpin atau pengambil keputusan dan pegawai Kelurahan di Kecamatan Maulafa harus konsisten dan inovatif dalam melaksanakan pekerjaan sehingga berimplikasi pada kinerja instansi dan tercapinyan tujuan reformasi birokrasi.

2. Pembahasan Hipotesis ke-2 (kedua); hasil pengujian hipotesis diatas menunjukkan bahwa, kemampuan kerja berpengaruh tidak signifikan terhadap kinerja pegawai. Dengan nilai t-statistik sebesar 0,698 dan nilai orginal sample/p-value sebesar 0,485. Dengan demikian maka hipotesis kesatu Ha ditolak dan Ho diterima. Dalam hal ini semakin meningkat motivasi kerja pegawai maka akan semakin meningkat kinerja pegawai. Hasil ini sesuai dengan penelitian yang dilakukan Widyastuti, dkk. (2017) menunjukkan bahwa motivasi kerja berpengaruh tidak signifikan terhadap kinerja Aparatur. Hasil penelitian ini menunjukkan bahwa ketika kebutuhan pegawai kurang terpenuhi maka motivasi kerja pegawai menjadi rendah. Kebutuhan pegawai merupakan suatu harapan yang diinginkan oleh pegawai dalam melaksanakan pekerjaan, jika harapan itu dapat menjadi 
kenyataan maka pegawai akan cenderung meningkatkan motivasi kerjanya, (Hasibuan, 2005:234). Ngaithe, dkk. (2016) mengatakan penyelarasan kebutuhan individu dengan kebutuhan suatu organisasi merupakan strategi fundamental motivasi. Kebutuhan pegawai merupakan suatu harapan yang diinginkan oleh pegawai dalam melaksanakan pekerjaan, jika harapan itu dapat menjadi kenyataan maka pegawai akan cenderung meningkatkan motivasi kerjanya, tetapi sebaliknya apabila harapan itu tidak tercapai akibatnya pegawai akan menjadi malas.

Hasil penelitian ini juga membuktikan bahwa teori kebutuhan Maslow tidak diterapkan dengan baik oleh pemimpin atau pengambil keputusan pada Kelurahan di Kecamatan Maulafa Kota Kupang. Graham dan Messner, 2000; Nadler dan Lawler, 1979 (dalam Kaur, 2013:1064) mengatakan bahwa ada sedikit data empiris yang mendukung kesimpulan Maslow (teori kebutuhan Maslow). Kemudian Önday (2016:102) menambahkan bahwa selama bertahun-tahun peneliti cenderung mengkritik teori kebutuhan Maslow, para peneliti mengatakan teori kebutuhan Maslow tidak relevan di sebagian besar dunia karena bersifat barat. Lebih lanjut Onday mengatakan bahwa berbeda dengan pernyataan semacam itu, teori hierarki kebutuhan Maslow terus relevan di setiap bidang sebagai analisis terbaik. Terlepas dari kritik dan dukungan terhadap teori kebutuhan Maslow, penelitian ini juga mendukung teori kebutuhan Maslow sehingga digunakan sebagai teori pendukung motivasi kerja pegawai. Namun, harus disadari bahwa seringkali dalam penerapannya belum sesuai sehingga teori tidak relevan. Sebagaimana yang dikatakan Greenberg \& Baron (dalam Kachalla, 2014:44) bahwa nilai terbesar dari teori kebutuhan Maslow terletak pada implikasi praktis yang dimilikinya untuk setiap pengelolaan organisasi.

3. Pembahasan Hipotesis ke-3 (ketiga); hasil pengujian hipotesis diatas menunjukkan bahwa, lingkungan kerja berpengaruh signifikan terhadap kinerja pegawai dengan nilai t-statistik sebesar 4,030 dan nilai orginal sample/p-value sebesar 0,000 . Dengan demikian maka hipotesis ketiga Ha diterima dan Ho ditolak. Dalam hal ini semakin meningkat lingkungan kerja maka akan semakin meningkat kinerja secara signifikan. Konsisten dengan penelitian yang dilakukan Rosa (2015); Rumengan dan Mekel (2015);
Handayani (2016) menemukan bahwa, lingkungan kerja berpengaruh signifikan terhadap kinerja karyawan/pegawai.

Hasil penelitian ini membuktikan bahwa teori human relation dapat diterapkan dengan baik oleh pemimpin atau pengambil keputusan maupun pegawai pada Kelurahan di Kecamatan Maulafa. Konsisten dengan penelitian Anthony (2015:298) menunjukkan bahwa teori human relations dapat diterapkan pada bank dan keuangan lainnya di Nigeria.

4. Pembahasan Hipotesisi ke-4 (keempat); hasil pengujian hipotesis diatas menunjukkan bahwa, efikasi diri berpengaruh signifikan terhadap kinerja pegawai dengan nilai tstatistik sebesar 5,285 dan nilai orginal sample/p-value sebesar 0,000 . Oleh sebab itu, hipotesis keempat Ha diterima dan Ho ditolak. Konsisten dengan penelitian Sulaiman, dkk. (2014) self efficacy berpengaruh positif dan signifikan terhadap kinerja karyawan. Penelitian Murniningsih, dkk. (2013) terdapat pengaruh yang signifikan dan positif efikasi diri terhadap kinerja. Penelitian Liana dkk. (2016) menunjukkan self efficacy berpengaruh positif terhadap kinerja guru.

Hasil penelitian ini membuktikan bahwa teori penetapan tujuan dapat diterapkan dengan baik oleh pimpinan maupun pengambil keputusan pada Kelurahan di Kecamatan Maulafa Kota Kupang. teori ini mengatakan bahwa efikasi diri mempengaruhi tujuan terhadap kinerja, (Locke dan Latham dalam Yuwono, dkk., 2006:575). Tujuan secara sederhana berarti sesuatu yang dilakukan secara sadar untuk mencapai sesuatu, (Putri dan Priambodo, 2015:221).

5. Pembahasan Hipotesis ke-5 (kelima); hasil pengujian hipotesis diatas menunjukkan bahwa, Kemampuan kerja berpengaruh tidak signifikan terhadap kinerja pegawai yang dimoderasi lingkungan kerja dengan nilai tstatistik sebesar 1,542 dan nilai orginal sample/p-value sebesar 0,124. Dengan demikian maka hipotesis kelima Ha ditolak dan Ho diterima. Dengan demikian maka lingkungan kerja tidak mampu memperkuat pengaruh kemampuan terhadap kinerja pegawai. Hal ini diakibatkan karena kesalahan-kesalahan kecil diawal pegawai melaksanakan pekerjaan atau pelaksanaan pekerjaan oleh pegawai yang tidak berkemampuan akan menghasilkan akhir yang buruk. Poincare mengatakan bahwa apabila terjadi perbedaan kecil dalam kondisi 
awal akan menghasilkan kejadian yang sangat hebat dalam fenomena akhir. Kesalahan kecil yang terjadi sebelumnya akan menghasilkan kesalahan besar pada akhirnya. Ini menunjukkan bahwa sistem dan kejadian tidak dapat diprediksi. Teori Poincare semakin diperkuat oleh Edward Lorenz di tahun 1960-an. Lorenz berpendapat bahwa sedikit perubahan dalam sistem meskipun dilihat sebagai kesalahan kecil berpotensi memiliki pengaruh besar pada keseluruhan sistem itu sendiri, (Somoye, 2015:21).

6. Pembahasan Hipotesis ke-6 (keenam); hasil pengujian hipotesis diatas menunjukkan bahwa, motivasi kerja berpengaruh signifikan terhadap kinerja pegawai yang dimoderasi lingkungan kerja dengan nilai t-statistik sebesar 2,404 dan nilai orginal sample/pvalue sebesar 0,017 . Dengan demikian maka hipotesis keenam Ha diterima dan Ho ditolak. Dalam hal ini lingkungan kerja dapat meningkatkan pengaruh motivasi kerja terhadap kinerja pegawai. Sesuai dengan penelitian Rosinda (2013) bahwa lingkungan kerja sebagai variabel moderasi mampu memperkuat pengaruh motivasi terhadap kinerja karyawan. Ermayanti (dalam Husaini, 2014:76) mengemukakan bahwa pemahaman motivasi, baik yang ada dalam diri karyawan (pegawai) maupun yang berasal dari lingkungan (kerja) akan dapat membantu dalam peningkatan kinerja. Terciptanya lingkungan kerja pegawai Kelurahan di Kecamatan Maulafa Kota Kupang yang kondusif akan mampu meningkatkan motivasi pegawai dalam menyelesaikan suatu pekerjaan yang diberikan kepadanya. Sunyoto (2012:43) menambahkan bahwa, lingkungan kerja merupakan bagian komponen yang sangat penting di dalam karyawan (pegawai) melakukan aktivitas kerja.

Hasil penelitian ini membuktikan bahwa teori motivasi Claude S. George dapat diterapkan dengan baik pada Kelurahan di Kecamatan Maulafa Kota Kupang. Teori ini menyatakan bahwa seseorang mempunyai kebutuhan yang berhubungan dengan tempat dan suasana di lingkungan ia bekerja, (Hasibuan, 2005:233).

7. Pembahasan Hipotesis ke-7 (ketujuh); hasil pengujian hipotesis diatas menunjukkan bahwa, Kemampuan kerja berpengaruh tidak signifikan terhadap kinerja pegawai yang dimoderasi efikasi diri dengan nilai t-statistik sebesar 0,563 dan nilai orginal sample/pvalue sebesar 0,573 . Dengan demikian maka hipotesis ketujuh Ha ditolak dan Ho diterima. Dalam hal ini efikasi diri memperlemah pengaruh kemampuan kerja terhadap kinerja pegawai. Hasil penelitian ini menunjukkan bahwa efikasi diri yang dimiliki pegawai tidak mampu meningkatkan kemampuan kerja terhadap kinerja pegawai. Hal ini diakibatkan rendahnya efikasi diri yang dimiliki pegawai. Konsisten dengan penelitian yang dilakukan Vancouver, Thompson \& Williams (2001); Vancouver, Thompson, Tischner \& Putka (2002) menunjukkan self-efficacy terhadap kemampuan seseorang dan penetapan tujuan adalah melemahkan diri sendiri, (Bandura dan Locke, 2003:87). Inkonsisten dengan penelitian yang dilakukan Locke dan Latham di Asia, Australia, Eropa dan Amerika Utara menemukan bahwa teori penetapan tujuan memiliki dampak terhadap kinerja dalam berbagai kontes dan lintas waktu, (Bruce, dkk., 2015:4). Robbins dalam Molan (2007:229) mengatakan bahwa makin tinggi efikasi diri atau keefektifan diri (self efficacy) anda makin besarlah kepercayaan diri anda terhadap kemampuan untuk berhasil dalam tugas tertentu. Demikian juga pegawai Kelurahan di Kecamatan Maulafa Kota Kupang jika memiliki efikasi diri yang tinggi/positif akan yakin mampu meningkatkan kemampuan atau mampu melakukan suatu pekerjaan yang diberikan kepadanya. Abidin, dkk. (2016:2) menambahkan bahwa karyawan (pegawai) yang memiliki self-efficacy atau efikasi diri positif akan yakin untuk mampu melakukan suatu pekerjaan yang diberikan kepadanya.

8. Pembahasan Hipotesis ke-8 (kedelapan); hasil pengujian hipotesis diatas menunjukkan bahwa, motivasi kerja berpengaruh tidak signifikan terhadap kinerja pegawai yang dimoderasi efikasi diri dengan nilai t-statistik sebesar 1,962 dan nilai orginal sample/pvalue sebesar 0,050. Dengan demikian maka hipotesis kedelapan Ha ditolak dan Ho diterima. Dalam hal ini efikasi diri memperlemah pengaruh motivasi kerja terhadap kinerja pegawai. Hasil penelitian ini menunjukkan bahwa efikasi diri yang dimiliki pegawai tidak mampu meningkatkan motivasi kerja terhadap kinerja pegawai. Hal ini diakibatkan rendahnya efikasi diri pegawai yang disebabkan pegawai sering gagal dalam menyelesaikan tugas yang sulit. Slameto (dalam Parasara dan Surya, 2016:3224) mengatakan bahwa, keberhasilan seseorang 
dalam menyelesaikan tugas atau tantangan yang sulit dapat menyebabkan meningkatnya self-efficacy yang berpengaruh pada motivasi yang lebih kuat terhadap tantangan atau tugas tersebut. Serta Azwar (dalam Parasara dan Surya, 2016:3223) menambahkan bahwa tinggi rendahnya self-efficacy yang dipersepsikan akan memotivasi individu secara kognitif untuk bertindak lebih persisten (konsisten) dan terarah, terutama apabila tujuan yang hendak dicapai lebih jelas.

Hasil penelitian ini membuktikan bahwa teori penetapan tujuan belum diterapkan dengan baik oleh pimpinan maupun pengambil keputusan pada Kelurahan di Kecamatan Maulafa Kota Kupang dalam meningkatkan motivasi kerja terhadap kinerja pegawai. Teori ini mengatakan bahwa efikasi diri mempengaruhi tujuan terhadap kinerja, (Locke dan Latham dalam Yuwono, dkk., 2006:575). Teori ini memfokuskan pada perbedaan aspek sifat manusia atau aspek internal dan berusaha mengungkap proses pemikiran dalam menentukan pilihan. Teori penetapan tujuan yang dikembangkan oleh Lock dan Latham menyatakan bahwa faktorfaktor penting yang memengaruhi pilihan yang dibuat oleh individu dapat dilihat dari seberapa besar usaha/motivasi yang dilakukan oleh individu tersebut, (Lock dan Latham dalam Mindarti, 2015:61-62). Penelitian Bandura dan Locke (2003:87) memverifikasi bahwa self-efficacy yang dirasakan dari penetapan tujuan dapat meningkatkan motivasi dan kinerja.

\section{KESIMPULAN}

Berdasarkan tujuan penelitian dan hasil pengujian hipotesis, maka dapat disimpulkan secara bahwa:

a. Hasil pengujian hipotesis kesatu ditemukan bukti secara statistik kemampuan kerja berpengaruh tidak signifikan terhadap kinerja pegawai Kelurahan di Kecamatan Maulafa. Dengan demikian maka hipotesis kesatu Ha ditolak dan $\mathrm{HO}$ diterima.

b. Hasil pengujian hipotesis kedua ditemukan bukti secara statistik motivasi kerja berpengaruh tidak signifikan terhadap kinerja pegawai Kelurahan di Kecamatan Maulafa. Dengan demikian maka hipotesis kedua Ha ditolak dan $\mathrm{HO}$ diterima.

c. Hasil pengujian hipotesis ketiga ditemukan bukti secara statistik lingkungan kerja berpengaruh signifikan terhadap kinerja pegawai Kelurahan di Kecamatan Maulafa.
Dengan demikian maka hipotesis ketiga Ha diterima dan $\mathrm{HO}$ ditolak.

d. Hasil pengujian hipotesis keempat ditemukan bukti secara statistik efikasi diri berpengaruh signifikan terhadap kinerja pegawai Kelurahan di Kecamatan Maulafa. Dengan demikian maka hipotesis keempat Ha diterima dan H0 ditolak.

e. Hasil pengujian hipotesis kelima ditemukan bukti secara statistik kemampuan kerja berpengaruh tidak signifikan terhadap kinerja pegawai Kelurahan di Kecamatan Maulafa yang dimoderasi lingkungan kerja. Dengan demikian maka hipotesis kelima Ha ditolak dan $\mathrm{HO}$ diterima.

f. Hasil pengujian hipotesis keenam ditemukan bukti secara statistik motivasi kerja berpengaruh signifikan terhadap kinerja pegawai Kelurahan di Kecamatan Maulafa yang dimoderasi lingkungan kerja. Dengan demikian maka hipotesis keenam Ha diterima dan $\mathrm{HO}$ ditolak.

g. Hasil pengujian hipotesis ketujuh ditemukan bukti secara statistik kemampuan kerja berpengaruh tidak signifikan terhadap kinerja pegawai Kelurahan di Kecamatan Maulafa yang dimoderasi efikasi diri. Dengan demikian maka hipotesis ketujuh Ha ditolak dan HO diterima.

h. Hasil pengujian hipotesis kedelapan ditemukan bukti secara statistik motivasi kerja berpengaruh tidak signifikan terhadap kinerja pegawai Kelurahan di Kecamatan Maulafa yang dimoderasi efikasi diri. Dengan demikian maka hipotesis kedelapan Ha ditolak dan HO diterima.

\section{SARAN}

Saran yang bisa disampaikan dari hasil penelitian yang didapat adalah sebagai berikut:

a. Kemampuan kerja pegawai perlu diperbaiki dan ditingkatkan sehingga kemampuan kerja menjadi optimal yang berimplikasi pada kinerja pegawai dan tercapainya tujuan reformasi birokrasi;

b. Motivasi kerja pegawai perlu diperbaiki dan ditingkatkan sehingga motivasi kerja menjadi optimal yang berimplikasi pada kinerja pegawai dan tercapainya tujuan reformasi birokrasi;

c. Lingkungan kerja yang aman dan nyaman perlu pertahankan dengan baik agar selalu tercipta suasana yang kondusif yang berimplikasi pada kinerja pegawai dan tercapainya tujuan reformasi birokrasi; 
d. Efikasi diri yang dimiliki pegawai perlu dipertahankan dan ditingkatkan agar selalu optimal dalam setiap situasi dan kondisi .

e. Kinerja pegawai perlu dipertahankan dengan baik dan dapat ditingkatkan agar lebih optimal yang berimplikasi pada tercapainya tujuan reformasi birokrasi.

\section{KETERBATASAN}

Penelitian ini juga masih memiliki keterbatasan-keterbatasan. Dengan keterbatasan ini, diharapkan peneliti selanjutnya untuk melakukan perbaikan. Adapun keterbatasan penelitian ini adalah kurang berpartisipasinya responden dalam mengisi kuesioner yang dibagikan, hal ini dapat dilihat dari 117 kuesioner yang dibagikan hanya 66 kuesioner yang diisi atau sebesar 56,41\%; terdapat beberapa butir pertanyaan kemampuan kerja yang tidak valid sehingga berakibat pada hasil perhitungan yang melibatkan variabel kemampuan kerja. Sehingga bagi peneliti selanjutnya agar mengambil sampel yang lebih besar dan diusahakan untuk responden mengisi seluruh kuesioner yang dibagikan serta bagi responden agar bersedia mengisi seluruh kuesioner dengan baik untuk tercapainya penilaian yang optimal dan dapat digeneralisasi serta demi inovasi perkembangan ilmu pengetahuan.

\section{DAFTAR PUSTAKA}

Abdulkarim Jailan, 2016. Pengaruh Kemampuan Kerja, Motivasi Kerja dan Fasilitas Kerja terhadap Kinerja Pegawai Kantor Pertanahan Kota Palangka Raya. JSM (Jurnal Sains Manajemen) Program Magister Sains Manajemen UNPAR, ISSN: 2302-1411, Volume V, Nomor 2, September 2016, pp: 142-154.

Abidin Zainal Iqbal Muhammad; Pangtuluran Yonathan dan Maria Siti, 2016. Pengaruh Kepuasan Kerja, Lingkungan Kerja dan Efikasi Diri Terhadap Komitmen Organisasi di Rumah Sakit SMC Samarinda. Akuntabel: Jurnal Ekonomi dan keuangan Volume 13, (1), ISSN: print: 0216-7743, ISSN: online: 2528-1135, http://journal.feb.unmul.ac.id.

Adianita Selfi Ance; Mujanah Siti \& Candraningrat, 2017. Kompetensi Karyawan, Emotional Quotient dan Self Efficacy Pengaruhnya terhadap Organizational Citizenship Behavior dan Kinerja Karyawan Pada Indomobil Grup di Surabaya. Journal of Research in
Economics and Management (Jurnal Riset Ekonomi dan Manajemen), Volume 17, No. 1, Januari - Juni (Semester I) 2017, Halaman 1-xx, DOI 10.17970/jrem.17.1701014.ID.

Anthony Aghoghovbiah Edemivwaye, 2015. Imperatives of Classical and Human Relations Management Approaches to Bank and Other Financial Institutions in Nigeria. The International Journal Of Humanities \& Social Studies (ISSN: 2321 - 9203), Vol 3 Issue 10, October, www.theijhss.com.

Bandura Albert, 2012. On the Functional Properties of Perceived Self-Efficacy Revisited. Journal of Management. Vol. 38 No. 1, January 2012, 9-44. DOI: 10.1177/0149206311410606. Downloaded from jom.sagepub.com by guest on July 24 , 2016.

Bandura Albert dan Locke A. Edwin, 2003. Negative Self-Efficacy and Goal Effects Revisited. Journal of Applied Psychology, Vol. 88, No. 1, 87-99. Copyright 2003 by the American Psychological Association, Inc. $\quad 0021-9010 / 03 / \$ 12.00 \quad$ DOI: 10.1037/0021-9010.88.1.87.

Beattie Stuart and Woodman Tim, Fakehy Mohammed, Dempsey Chelsey, 2016. The Role of Performance Feedback on the SelfEfficacy-Performance Relationship, Sport, Exercise, and Performance Psychology, Vol. 5, No.1, 1-13, (C) 2015 American Psychological Association,2157$3905 / 16 / \$ 12.00$ http://dx.doi.org/10.1037/spy0000051.

Bruce Martin; J. Jeffrey McNally dan Taggar, 2015. Simon Determining the Importance of Self-Evaluation on the Goal-Performance Effect in Goal Setting: Primary Findings. Canadian Journal of Behavioural Science, 48 (2): 91-100. Canadian Psychological Association. http://dx.doi.org/10.1037/cbs0000025.

Cherian Jacob \& Jacob Jolly, 2013. Impact of Self Efficacy on Motivation and Performance of Employees. International Journal of Business and Management; Vol. 8, No. 14; 2013, ISSN: 1833-3850, E-ISSN: 18338119. doi:10.5539/ijbm.v8n14p80 URL: http://dx.doi.org/10.5539/ijbm.v8n14p80.

Dolphina Erlin, 2012. Pengaruh Motivasi, Kepemimpinan dan Budaya Kerja terhadap Kepuasan Kerja Karyawan serta dampaknya pada Kinerja Perusahaan. Seminar Nasional Teknologi Informasi \& 
Komunikasi Terapan (Semantik). ISBN: 979-26-0255-0.

Elvera, 2016. Pengaruh Pelatihan dan Self Efficacy terhadap Kinerja Karyawan pada Sekolah Tinggi Ilmu Ekonomi (STIE) Lembah Dempo Kota Pagaralam. Jurnal Ekonomia, Vol. 6, No. 2, Juli, ISSN: 1858 $-2451$

Emeka Nnamani and Eyuche Helen Ajagu, 2014. Environmental Factors and Organizational Performance in Nigeria (A Study of Juhel Company). World Engineering \& Applied Sciences Journal 5 (3): 75-84, ISSN: 20792204.

DOI: 10.5829/idosi.weasj.2014.5.3.1124.

Fadillah Rozi; Sulastini \& Hidayati Noor, 2017. Pengaruh Kompetensi, Disiplin Kerja dan Lingkungan Kerja terhadap Kinerja Karyawan pada Kantor Bank Kalsel Cabang Pembantu di Banjarmasin. Jurnal Bisnis dan Pembangunan, Edisi JanuariJuni, Vol 6, No. 1, ISSN: 2541-178X.

Farlen Frans, 2011. Pengaruh Motivasi Kerja dan Kemampuan Kerja terhadap Kinerja Karyawan (Studi pada Karyawan PT. United Tractors, Tbk Samarinda), Skripsi, Jurusan Administrasi Bisnis Fakultas Ilmu Sosial dan Ilmu Politik Universitas Pembangunan Nasional "Veteran" Yogyakarta, Publikasi.

Gibson L James, Donnelly Jr. H. James dan Ivancevich M. John, 1995. Fundamentals of Management. by Richard D. Irwin, Inc. All Right Reserved. Alih Bahasa, Ichyaudin Zuhad, 1996. Manajemen. Edisi Kesembilan Jilid 1. Jakarta: Erlangga. ISBN: 979-411-344-1.

Gultom Yansen, 2015. Pengaruh Pengetahuan, Pengalaman Spesifik, dan Self Efficacy terhadap Kinerja Auditor dengan Kompleksitas Tugas Sebagai Variabel Moderasi. Jurnal TEKUN/Volume VI, No. 01, Maret 2015: 36-53.

Hanafi Dwilaksono Bayu \& Yohana Corry, 2017. Pengaruh Motivasi, dan Lingkungan Kerja, terhadap Kinerja Karyawan, dengan Kepuasan Kerja Sebagai Variabel Mediasi pada PT BNI Lifeinsurance. Jurnal Pendidikan Ekonomi dan Bisnis (JPEB) Vol. 5 No. 1 Maret 2017, E-ISSN: 23022663, DOI: doi.org/10.21009/JPEB.005.1.6, http://doi.org/10.21009/JPEB.

Handayani Dwi Rina, 2016. Pengaruh Lingkungan dan Semangat Kerja terhadap Kinerja PNS Balitsa Lembang, Pariwisata, Vol. II No.1 April, ISSN: 2355-6587.
Hasballah; Yunus Mukhlis dan Ibrahim Mahdani, 2015. Pengaruh Kecerdasan Emosional, Lingkungan Kerja Dan Motivasi Terhadap Kinerja Pegawai Serta Implikasinya Pada Kinerja Organisasi Dinas Kehutanan Dan Perkebunan Kabupaten Pidie. Jurnal Manajemen Pascasarjana Universitas Syiah Kuala, Volume 4, No. 2, Mei, ISSN 23020199, pp. 98-107.

Hasibuan P.S. Malayu H., 2005. Manajemen Dasar, Pengertian, dan Masalah. Edisi Revisi, Cetakan keempat, Mei. Jakarta: Bumi Aksara. ISBN: 979-526-546-6.

Heliawan Agung Yuge, 2016. Analisis Kinerja Karyawan PT Novell Pharmaceutical Laboratories dengan Menggunakan Variabel Kompensasi, Lingkungan Kerja dan Motivasi. Jurnal Akuntansi dan Pajak Vol. 16 No. 02, Januari 2016, ISSN: 1412$629 X$.

Husaini, Darussman dan Amri, 2014. Pengaruh Kompensasi, Penempatan dan Rotasi Pekerjaan terhadap Motivasi Kerja serta Implikasinya pada Kinerja Pegawai Kantor Pusat administrasi universitas syiah kuala. Jurnal Manajemen Pascasarjana Universitas Syiah Kuala, Volume 3, No. 1, Februari, pp. 74-82, ISSN: 2302-0199.

Imran Rabia, Fatima Afsheen, Zaheer Arshad, Yousaf Imran and Batool Iram, 2012. How to Boost Employee Performance: Investigating the Influence of Transformational Leadership and Work Environment in a Pakistani Perspective. Middle-East Journal of Scientific Research 11 (10). 1455-1462, ISSN: 1990-9233. DOI: 10.5829/idosi.mejsr.2012.11.10.741.

Ismiyanto dan Riyadi Bambang, 2014. Pengaruh Perilaku Pimpinan, Kepuasan Kerja, Lingkungan Kerja dan Kemampuan Kerja terhadap Kinerja Karyawan PT. BPR Central Artha-Tegal. Media Ekonomi dan Manajemen, Vol. 29, No. 2, Juli, ISSN : 085-1442.

Jansen Althea dan Samuel Michael O., 2014. Achievement of Organisational Goals and Motivation of Middle Level Managers within the Context of the Two-Factor Theory. Mediterranean Journal of Social Sciences, MCSER Publishing, Rome-Italy, Vol 5, No 16, ISSN: 2039-2117 (online), ISSN: 2039-9340 (print), Doi:10.5901/mjss.2014.v5n16p53.

Jayaweera Thushel, 2015. Impact of Work Environmental Factors on Job Performance, Mediating Role of Work 
Motivation: A Study of Hotel Sector in England. International Journal of Business and Management; Vol. 10, No. 3, ISSN: 1833-3850, E-ISSN: 1833-8119, Published by Canadian Center of Science and Education, doi:10.5539/ijbm.v10n3p271 URL: http://dx.doi.org/10.5539/ijbm.v10n3p271.

Kachalla Babagana, 2014. Review of the Role of Motivation on Employee Performance. Mediterranean Journal of Social Sciences MCSER Publishing, Rome-Italy. Vol. 5 No. 17, July. ISSN: 2039-2117 (online), ISSN: 2039-9340 (print). Doi:10.5901/mjss.2014.v5n17p39.

Kaseger Gledy Regina, 2013. Pengembangan Karir dan Self-Efficacy terhadap Kinerja Karyawan pada PT. Matahari Department Store Manado Town Square. Jurnal EMBA Vol.1 No.4 Desember, Hal. 906-916, ISSN 2303-1174.

Kaswan, 2013. Pelatihan dan Pengembangan untuk Meningkatkan Kinerja SDM. Bandung: Alfabeta, CV. ISBN: 978-6028800-84-6.

Kaur Avneet, 2013. Maslow's Need Hierarchy Theory: Applications and Criticisms. Global Journal of Management and Business Studies. ISSN: 2248-9878 Volume 3, Number 10 (2013), pp. 10611064, (C) Research India Publications, http://www.ripublication.com/gjmbs.htm.

Khojasteh Laleh; Shokrpour Nasrin \& Afrasiabi Maedeh, 2016. The Relationship between Writing Self-efficacy and Writing Performance of Iranian EFL Students. International Journal of Applied Linguistics \& English Literature, ISSN: 2200-3592 (Print), ISSN 2200-3452 (Online), Vol. 5 No. $\quad 4$; July. doi:10.7575/aiac.ijalel.v.5n.4p.29.

Kompas.com, 2011. PNS, Kerajaan Terburuk di Indonesia. Kamis, 18 Agustus 2011. Diakses dari http://nasional.kompas.c om/read/2011/08/18/20340772/pns.kerajaan .terburuk.di.indonesia. pada tanggal 09 Agustus 2016, jam 22.28 Wita.

Kompas.com, 2014. Pelayanan Publik Masih Buruk, Moratorium CPNS Dinilai Berisiko. Diakses dari http://nasional.kompas.com/read/2014/11/1 2/06351101/Pelayanan.Publik.Masih.Buruk .Moratorium.CPNS.Dinilai.Berisiko. pada tanggal 09 Agustus 2016, jam 22.30 Wita.

Kompas.com, 2015. Wapres Minta Tunjangan Kinerja PNS Ditinjau Kembali. Diakses dari

http://nasional.kompas.com/read/2015/07/0 9/19160271/Wapres.Minta.Tunjangan.Kine rja.PNS.Ditinjau.Kembali. pada tanggal 09 Agustus 2016, jam 22.31 Wita.

Kompasiana.com, 2015. Wagub Meminta PNS yang Baru Dilantik Tingkatkan Kinerja. Diakses dari http://www.kompasiana.com/beritajakarta/ wagub-meminta-pns-yang-baru-dilantiktingkatkan kinerja_ 55e6e0b9ac9273510 a744f5f. pada tanggal 09 Agustus 2016, jam 22.32 Wita.

Kontu Oktafia; Mekel Peggy \& Moniharapon Silcyljeova, 2015. Pengaruh Pendidikan, Kemampuan Kerja dan Kompensasi terhadap Kinerja Pegawai pada Kantor Dinas Sosial Kota Manado. Jurnal EMBA Vol.3 No.1 Maret 2015, Hal. 748-759, ISSN: 2303-1174.

Laan Rahmat, 2016. Mengingatkan Urgensi Pelayanan Publik. Pos Kupang, 2 September 2016 No. 261/Tahun XXIV.

Laan Rahmat, 2016. Pengaruh Kompensasi dan Gaya Kepemimpinan terhadap Motivasi dan Kinerja Pegawai, Jurnal Manajemen, November, Vol. 2, No. 2, ISSN: 12456578.

Liana Lie; Rijanti Tristiana \& Herdiyanto, 2016. Pengaruh Motivasi dan Self Efficacy terhadap Kinerja Guru dimoderasi Gaya Kepemimpinan Transformasional (Studi pada Guru-Guru SMP Negeri SeKecamatan Bojong Kabupaten Pekalongan). Prosiding Seminar Nasional Multi Disiplin Ilmu \& Call For Papers Unisbank (SENDI_U) KE-2 Tahun 2016, Kajian Multi Disiplin Ilmu dalam Pengembangan IPTEKS untuk Mewujudkan Pembangunan Nasional Semesta Berencan (PNSB) sebagai Upaya Meningkatkan Daya Saing Global. Unisbank Semarang, 28 Juli, ISBN: 978979-3649-96-2.

Luthans Fred, 2005. Organizational Behavior $10^{\text {th }}$ Edition. The McGraw-Hill Companies, Inc. Terjemahan, Yuwono, Vivin Andhika, Purwanti, Shekar, P, Th. Arie dan Rosari, Winong, 2006. Perilaku Organisasi Edisi 10. Yogyakarta: ANDI. ISBN: 979-763140-0.

Machfud; Yunus Mukhlis dan Amri, 2015. Pengaruh Kemampuan SDM dan Kejelasan Aturan Terhadap Kinerja Anggota dan Implikasinya Terhadap Kinerja Polresta Banda Aceh, Jurnal Manajemen 
Pascasarjana Universitas Syiah Kuala Volume 4, No. 2, Mei, pp. 170- 179, ISSN: 2302-0199.

Mamangkey Junita Trisofia; Tumbel Altje dan Uhing Yantje, 2015. Pengaruh Pelatihan, Pengalaman dan Lingkungan Kerja terhadap Kinerja Karyawan pada PT. Bangun Wenang Beverages Company Manado. Jurnal EMBA Vol.3 No.1 Maret, Hal.737-747. ISSN: 2303-1174.

Mangkunegara Prabu Anwar. A.A., 2013. Manajemen Sumber Daya Manusia Perusahaan. Bandung: PT. Remaja Rosdakarya. ISBN: 979-514-929-6.

Mariadi; Nasir Azis dan M.Shabri Abd. Majid, 2015. Pengaruh Kompensasi, Motivasi Kerja dan Lingkungan Kerja terhadap Kinerja Karyawan serta Implikasinya terhadap Kinerja Kantor Pusat Operasional PT. Bank Aceh. Jurnal Manajemen. Vol.4, No.2, Mei, Hal:180189, ISSN: 2302-0199. Pascasarjana : Universitas Syiah Kuala.

Marliani Sari, 2016. Motivasi Kerja dan Kepuasan Kerja terhadap Kinerja Karyawan (Studi pada karyawan PT. Bank Negara Indonesia (Persero)Tbk Cabang Karawang). Jurnal Buana Akuntansi, ISSN: 2528-1119, Vol 1 No 1.

Media Indonesia.com, 2016. Kinerja PNS Pemkab Bandung Barat Menurun. Diakses dari http://www.mediaindonesia.com/news/read/ 51381/kinerja-pns-pemkab-bandung-baratmenurun /2016-06-16. pada 21 Desember 2016 jam 18.45 Wita.

Merdeka.com, 2013. Peningkatan kualitas PNS jangan hanya gembar gembor. Diakses dari http://www.merdeka.com/uang/peningkatan -kualitas-pns-jangan-hanya-gembar gembor.html. Pada tanggal 09 Agustus 2016, jam 23.15.

Mindarti Sri Ceacilia, 2015. Pengaruh Karakteristik Individu Terhadap Kinerja Auditor. Jurnal Ekonomi dan Bisnis, Volume XVIII No. 3, Desember, ISSN: 1979-6471.

Muliana, Hafasnuddin, Ibrahim, 2015. Pengaruh Budaya Organisasi, Pengembangan Karir Dan Kepuasan Kerja Terhadap Kinerja Karyawan Serta Dampaknya Pada Kinerja Bank Bri Cabang Bireuen. Jurnal Manajemen Pascasarjana Universitas Syiah Kuala. pp. 202-210, ISSN: 2302-0199.

Murniningsih Rochiyati, Zuhriyah Eni dan Fitrilia Martina, 2016. Faktor Psikologis Karyawan \& Pengaruhnya Terhadap
Kinerja UMKM, The 4th University Research Coloquium, ISSN: 2407-9189.

Nawawi Hadari H., 2003. Manajemen Sumber Daya Manusia Untuk Bisnis yang Kompetitif. Cetakan Kelima. Yogyakarta: Gadjah Mada University Press. ISBN: 979420-407-2.

Ngaithe Leonard; K'Aol George; Lewa Peter dan Ndwiga Michael, 2016. Effect of Idealized Influence and Inspirational Motivation on Staff Performance in State Owned Enterprises in Kenya. European Journal of Business and Management. Vol.8, No.30, ISSN: 2222-1905, (Paper) ISSN: 22222839 (Online). www.iiste.org.

Novyanti Sagita Joyce, 2015. Pengaruh Motivasi Kerja, Lingkungan Kerja dan Disiplin Kerja terhadap Kinerja Pegawai pada Bappeda Provinsi Sulawesi Tengah. eJurnal Katalogis, Volume 3 Nomor 1, Januari 2015 hlm 105-115, ISSN: 23022019.

Nurcahyani Made Ni \& Adnyani Dewi A.G.I, 2016. Pengaruh Kompensasi dan Motivasi terhadap Kinerja Karyawan dengan Kepuasan Kerja Sebagai Variabel Intervening. E-Jurnal Manajemen Unud, Vol. 5, No.1, 2016: 500-532, ISSN: 23028912.

Nusaku Bellany Okta Legendaria; Negara Jaya Danes \& Retawati Anike, 2014. Analisis Pengaruh Kemampuan dan Kompetensi terhadap Kinerja Pegawai (Studi Pada Badan Pemberdayaan Perempuan dan Keluarga Berencana Kabupaten Kotawaringin Timur), JSM (Jurnal Sains Manajemen), Program Magister Sains Manajemen UNPAR, Volume III, Nomor 1, April 2014, ISSN: 2302-1411.

Önday Özgür, 2016. Human Resource Theory: From Hawthorne Experiments of Mayo to Groupthink of Janis. Global Journal of Human Resource Management, Vol.4, No.1, pp.95-110, February, Published by European Centre for Research Training and Development UK (www.eajournals.org). ISSN: 2053-5686(Print), ISSN: 2053-5694 (Online).

Parasara Indra Agung Bagus Ida \& Surya Ketut Bagus Ida, 2016. Pengaruh Self Efficacy terhadap Motivasi dan Kepuasan Kerja Karyawan Inna Grand Bali Beach Hotel. EJurnal Manajemen Unud, Vol. 5, No. 5, 4219 - 3247 ISSN: 2302-8912.

Pos Kupang, 2013. Tiga SKPD Kabupaten TTS Kinerja Terburuk. Diakses dari 
http://kupang.tribunnews.com/2013/03/10/ tiga-skpd-kabupaten-tts-kinerja-terburuk. pada tanggal 09 Agustus 2016, jam 22.35 Wita.

Pos Kupang.com, 2015. Bongkar Kinerja Buruk Pimpinan dan Staf di Kanwil Kemenkumham Provinsi NTT. Diakses dari http://kupang.tribunnews.com/2015/12/16/b ongkar-kinerja-buruk-pimpinan-dan-staf-dikanwil-kemenkumham-provinsi-ntt. pada tanggal 09 Agustus 2016, jam 22.39 Wita.

Pos Kupang.com, 2015. Bupati Elias Djo: Kinerja Rendah Harus Mundur. Diakses dari http://kupang.tribunnews.com/2015/02/28/b upati-elias-djo-kinerja-rendah-harusmundur. pada tanggal 09 Agustus 2016, jam 22.36 Wita.

Pos Kupang.com, 2015. Falens Sebut Masyarakat Tidak Puas Terhadap Kinerja Birokrasi. Diakses dari http://kupang.tribunnews.com/2015/11/14/f alens-sebut-masyarakat-tidak-puasterhadap-kinerja-birokrasi. pada tanggal 09 Agustus 2016, jam 22.38 Wita.

Pos Kupang.com, 2015. Kinerja PNS Ende Masih Jauh dari Harapan. Diakses dari http://kupang.tribunnews.com/2015/06/20/k inerja-pns-ende-masih-jauh-dari-harapan. pada tanggal 09 Agustus 2016, jam 22.37 Wita.

Pos Kupang.com, 2016. Bupati Kupang Soroti Kinerja Para Pejabat. Diakses dari http://kupang.tribunnews.com/2016/12/08/b upati-kupang-soroti-kinerja-para-pejabat. pada tanggal 21 Desember 2016, jam 19.05 Wita.

Praptiestrini, 2016. Pengaruh Kepemimpinan, Lingkungan Kerja, dan Disiplin Kerja, terhadap Motivasi Kerja Pegawai Dinas Pariwisata dan Kebudayaan Kabupaten Karanganyar. Jurnal Paradigma Vol. 14, No. 01, Februari-Juli, ISSN: 1693-0827.

Pratama Anggi, 2015. Pengaruh Lingkungan Kerja Terhadap Kinerja Pegawai pada Badan Pelayanan Perijinan Terpadu dan Penanaman Modal (BPPM) Di Kota Bontang. eJournal Ilmu Administrasi Bisnis, 2015, 3 (2): 351-362, ISSN: 23555408, ejournal.adbisnis.fisip-unmul.ac.id.

Putri Eka Nurdiana, Hakim Abdul, dan Makmur M., 2015. Pengaruh Motivasi Kerja dan Kemampuan Kerja terhadap Komitmen Organisasional dan Kinerja Pegawai. JISIP: Jurnal Ilmu Sosial dan Ilmu Politik, ISSN: 2442-6962 Vol. 4, No. 1, www.publikasi.unitri.ac.id.
Putri Melati Renata dan Priambodo Anung, 2015. Pengaruh Efikasi Diri, Penetapan Tujuan dan Kepuasan Kerja Pada Pengembangan Kompetensi Guru Pendidikan Jasmani, Olahraga dan Kesehatan (Studi Pada Guru Pendidikan Jasmani, Olahraga dan Kesehatan di SMA Negeri Se-Kota Surabaya). Jurnal Pendidikan Olahraga dan Kesehatan, Volume 03 Nomor 01 Tahun 2015, 220 - 226. ISSN: 2338-7981.

Rahadi Dedi Rianto, 2010. Manajemen Kinerja Sumber Daya Manusia, Cetakan ke-I. Malang : Tunggal Mandiri Publishing. ISBN: 978-602-96351-8-8.

Rahmayanti Dina \& Afandi Idham, 2014. Analisis Pengaruh Kepemimpinan, Motivasi, Lingkungan Kerja, dan Kedisplinan terhadap Kinerja Karyawan (Studi Kasus: Operator Welding 1 A, PT. XYZ Motor). Jurnal Optimasi Sistem Industri, Vol. 13 No. 1, April 2014:556- 560, ISSN: 20884842.

Ramli Bin Shakir Mohammad dan Jusoh Bin Ahmad, 2015. Expectancy Theory Analysis to Conduct Research at Malaysian Research University. International Journal of Economics and Financial Issues, 2015, 5(Special Issue) 366-372. ISSN: 21464138. www.econjournals.com.

Ratnaningsih, 2016. Pengaruh Kemampuan Numerik dan Efikasi Diri terhadap Kemampuan Berpikir Kritis Matematis Mahasiswa, Prosiding, Konferensi Nasional Penelitian Matematika dan Pembelajarannya (KNPMP I) Universitas Muhammadiyah Surakarta, 12 Maret 2016. ISSN: 2502-6526.

Rimper Ribka Rinna \& Kawet Lotje, 2014. Pengaruh Perencanaan Karir dan Self Efficacy terhadap Kinerja Karyawan pada PT. PLN (Persero) Area Manado. Jurnal EMBA Vol.2 No.4 Desember, Hal. 413423, ISSN: 2303-1174.

Rizkansyah Irfan; Yunus Mukhlis \& Amri, 2015. Pengaruh Kecerdasan Emosional, Kompensasi dan Komitmen Terhadap Kinerja Karyawan Serta Implikasinya Terhadap Kinerja Kantor Pelayanan Pajak Pratama Banda Aceh, Jurnal Manajemen Pascasarjana Universitas Syiah Kuala Volume 4, No. 2, Mei, pp. 108- 117, ISSN: 2302-0180.

Robbins P. Stephen, 2003. Organizational Behavior, Tent Edition. by Pearson Education, Inc. Upper Saddle River: New Jersey. Terjemahan, Molan Benyamin, 
2007. Perilaku Organisasi, Edisi Kesepuluh/ Edisi Lengkap. Cetakan Kedua. PT. Indeks. ISBN: 979-683-713-7.

Rochman, 2008. Pengaruh Faktor Lingkungan Kerja, Usia Masa Pensiun, dan Tingkat Stres Kerja terhadap Kinerja Pegawai di Perseroan Terbatas (PT) Duta Ananda Textile Pekalongan. Tesis. Program Pascasarjana Universitas Sebelas Maret Surakarta. Publikasi.

Rokhilah \& Darmanto Susetyo, 2014. Pengaruh Kompetensi, Motivasi dan Lingkungan Kerja terhadap Kinerja Penyuluh Lapangan Program Keluarga Berencana (PLKB) di Kabupaten Pemalang, Media Ekonomi dan Manajemen, Vol. 29 No.68, 1 Januari, ISSN: 085-1442.

Rosa Hendri, 2015. Pengaruh Lingkungan Kerja dan Pelatihan terhadap Kinerja Karyawan PTPN VI Unit Ophir Sariak, e-Jurnal Apresiasi Ekonomi Volume 3, Nomor 2, Mei 2015: 187-197 ISSN: 2337 - 3997.

Rosinda Devi Kristi, 2013. Lingkungan kerja sebagai variabel moderasi antara pengaruh Motivasi dan Gaya Kepemimpinan terhadap Kinerja Karyawan di PT. Intan Sejati Klaten, Skripsi dipublikasi, Jurusan Manajemen Fakultas Ekonomi Universitas Pembangunan Nasional Veteran Yogyakarta.

Rumengan T. Lidya \& Mekel A. Peggy, 2015. Analisis Lingkungan Kerja terhadap Kinerja Pegawai pada Fakultas Ekonomi dan Bisnis Unsrat Manado, Jurnal EMBA Vol.3 No.1 Maret, Hal.890-899, ISSN: 2303-1174.

Sedarmayanti, 2007. Manajemen Sumber Daya Manusia, Reformasi Birokrasi dan Manajemen Pegawai Negeri Sipil. Cetakan Pertama: Juli. Bandung: PT. Refika Aditama. ISBN: 979-1073-83-x.

Setiawan Cahaya Kiki, 2015. Pengaruh Motivasi Kerja terhadap Kinerja Karyawan Level Pelaksana di Divisi Operasi PT. Pusri Palembang. PSIKIS-Jurnal Psikologi Islami Vol. 1 No. 2 Desember 2015 pp: 43-53, ISSN: 2502-728X.

Setiawan Joko, 2014. Analisa Pengaruh Pendidikan dan Pelatihan Karyawan terhadap Peningkatan Kinerja Karyawan pada PT. GICI Group Batam. Jurnal AKMENBIS Akademi Akuntansi Permata Harapan Vol III, No 01 ISSN: 2302-6847. Hal. 12-18, Maret.

Siburian Paningkat, 2014. Faktor Penentu Kinerja Kepala Sekolah Menengah Kejuruan.
Cakrawala Pendidikan, Juni 2014, Th. XXXIII , No. 2. pp. 257-266, ISSN: 02161370 .

Sindonews.com, 2012. Membangun Kepercayaan Karyawan Untuk Kinerja Lebih Baik. Jum'at, 9 November 2012. Halaman 1. Diakses dari http://ekbis.sindonews.com/read/686901/39 /membangun-kepercayaan-karyawan-untukkinerja-lebih-baik-1352430010 pada tanggal 9 Juni 2016, jam 19.35 Wita.

Sitohang Sonang; Soejono \& Winarningsih, 2012. Pengaruh Environment, Motivation, Regulation Terhadap Kinerja Pengrajin Sentra Industri Kecil Pande Besi Di Kabupaten Tulungagung. Jurnal Akuntansi, Manajemen Bisnis Dan Sektor Publik (JAMBSP). Vol. 8 No. 3-Juni, pp. $338-$ 361, ISSN: 1829 - 9857.

Sofyan Khairani Diana, 2013. Pengaruh Lingkungan Kerja Terhadap Kinerja Kerja Pegawai BAPPEDA. Malikussaleh Industrial Engineering Journal Vol.2 No.1, pp.18-23, ISSN: $2302934 X$.

Somoye Gbolahan Kehinde, 2015. Critical Review of the Management of Healthcare System in Nigeria: Emphasis on Health Workforce. Submitted to the Graduate School of Social Sciences in partial fulfillment of the requirements for the Master Degree In Health Care Administration. Institute Of Social Sciences-Girne American University. Publikasi.

Sopiah, 2008. Perilaku Organisasional. Edisi 1. Yogyakarta: CV. Andi Offset. ISBN: 978979-29-03-03-4.

Sudarmo \& Lukita Swasti Hendika, 2015. Pengaruh Gaya Kepemimpinan, Motivasi, Dan Disiplin Kerja Terhadap Kinerja Karyawan PT. Empat Enam Jaya Abadi Balikpapan. Jurnal Sains Terapan No. 1 Vol. 2 Juni, ISSN: 2406-8810.

Sugiyono, 2013. Metode Penelitian Kuantitatif, Kualitatif dan R\&D, Cetakan ke-19. Bandung: Alfabeta, CV. ISBN: 979-843364-0.

Suharso Puguh, 2009. Metode Penelitian Kuantitatif Untuk Bisnis: Pendekatan Filosofis dan Praktis. Cetakan Pertama. Jakarta Barat: PT Indeks. ISBN: 978-979062-073-5.

Sulaiman; Asnawi \& Matriadi Faisal, 2014. Pengaruh Pemberdayaan, Self Efficacy dan Budaya Organisasi terhadap Kinerja Karyawan PT. Surya Madistrindo Cabang 
Lhokseumawe dengan Kepuasan Kerja sebagai Variabel Intervening, Jurnal Ekonomi, Manajemen dan Akuntansi, Vol 4 No. 1 ISSN 2303 0542, Juni.

Sule Trisnawati Ernie dan Saefullah Kurniawan, 2005. Pengantar Manajemen Edisi Pertama. Cetakan Pertama. Jakarta: Renanda Media. ISBN: 979-3465-75-1.

Sumarsono Sonny, 2009. Teori dan Kebijakan Publik, Ekonomi Sumber Daya Manusia. Edisi Pertama, Cetakan Pertama. Yogyakarta: Graha Ilmu. ISBN: 978-979756-530-5.

Sundari, 2016. Pengaruh Kreativitas dan Kecerdasan Spiritual Terhadap Efikasi Diri dan Kemandirian Mahasiswa Studi Kasus: Jurusan Manajemen, Fakultas Ekonomi Universitas Islam Majapahit (UNIM) Mojokerto. Jurnal Ekonomi dan Dakwah Islam (Al-Tsiqoh). Volume 1 (01) 26-37. ISSN: 2502-8294.

Sunyoto Danang, 2012. Teori, Kuesioner, dan Analisis Data, Sumber Daya Manusia (Praktik Penelitian). Cetakan Pertama. Yogyakarta: CAPS (Center of Academic Publishing Service). ISBN: 978-602-932417-4.

Suwondo Indriani Diah \& Sutanto Madiono Eddy, 2015. Hubungan Lingkungan Kerja, Disiplin Kerja, Dan Kinerja Karyawan. Jurnal Manajemen Dan Kewirausahaan, Vol.17, NO. 2, September, 135-144. ISSN: 1411-1438 print / ISSN: 2338-8234 online. DOI: $10.9744 /$ jmk.17.2.135-144.

Tresiana Novita, 2015. Rasionalitas Kebijakan Pemekaran Kecamatan dan Kelurahan di Kota Bandar Lampung. Jurnal Bina Praja, Vol. 7, No, 2, Hal. 163 - 174. Jakarta, Juni 2015. ISSN: 2085-4323. Terakreditasi No. 531/Au1/P2MI-LIPI/04/2013.

Triswanto Heri Dan Triyanto, 2016. Pengaruh Pendidikan, Motivasi Kerja dan Kemampuan Kerja terhadap Kinerja Pegawai pada Dinas Pendapatan Pengelolaan Keuangan dan Asset Daerah Kabupaten Grobogan. Jurnal STIE Semarang Vol 8 No. 3 Edisi Oktober, ISSN: 2085-5656.

Undang-Undang Republik Indonesia Nomor 5 Tahun 2014 Tentang Aparatur Sipil Negara.

Wahyudi, 2011. Manajemen Konflik dalam Organisasi: Pedoman Praktis Bagi Pemimpin Visioner. Cetakan Keempat, Januari. Bandung: Alfabeta, CV. ISBN: 978-979-8433-32-9.
Wahyuningrum, 2008. Hubungan Kemampuan, Kepuasan dan Disiplin Kerja dengan Kinerja Pegawai di Kecamatan Tanggungharjo Kabupaten Grobogan. Tesis, Program Pascasarjana Universitas Diponegoro Program Studi: Magister Ilmu Administrasi Konsentrasi: Magister Administrasi Publik, Publikasi.

Widyaningrum Enny Mahmudah, 2012. Effects Of Organizational Culture And Ability On Organizational Commitment And Performance In Ibnu Sina Hospital Gresik. Academic Research International. Vol. 2, No. 1. ISSN-L: 2223-9553, ISSN: 22239944. www.journals.savap.org.pk.

Widyastuti Dina Amaylia; Idris Adam \& Burhanudin, 2017. Pengaruh Kemampuan Kerja dan Motivasi Terhadap Kinerja Aparatur di Sekretariat Daerah Provinsi Kalimantan Timur. e-Journal Administrative Reform, 5 (1): 55-68 ISSN: 2338-7637, ar.mian.fisip-unmul.ac.id (C) Copyright 2017.

Wijayanti Ratna \& Meftahudin, 2016. Pengaruh Kepemimpinan Islami, Motivasi dan Kepuasan Kerja terhadap Kinerja Karyawan dengan Lama Kerja Sebagai Variabel Moderating. Jurnal PPKM III (2016) 185-192 ISSN: 2354-869X.

Wirmayanis Suziana, 2014. Pengaruh Kemampuan Kerja Komitmen Organisasi Dan Motivasi Terhadap Kinerja Pegawai. Jurnal Dinamika Manajemen, vol. 2, No. 3, Juli-September, ISSN: 2338-123X.

Yunus Eddy, 2012. Pengaruh Kompetensi Sumber Daya Manusia terhadap Kinerja Pegawai KPPBC Tipe Madya Pabean Tanjung Perak Surabaya. Ekuitas: Jurnal Ekonomi dan Keuangan - Volume 16, Nomor 3, September, pp. 368 - 387, Akreditasi No. 110/DIKTI/Kep/2009.

Zainullah Amin; Suharyanto Agus \& Budio P. Sugeng, 2012. Pengaruh Upah, Kemampuan dan Pengalaman Kerja Terhadap Kinerja Pekerja Pelaksanaan Bekisting Pada Pekerjaan Beton. Jurnal Rekayasa Sipil. Volume 6, No. 2. ISSN: 1978-5658. 